\title{
Forage-based dairying in a water-limited future: Use of models to investigate farming system adaptation in southern Australia
}

\author{
D. F. Chapman, ${ }^{* 1}$ K. Dassanayake, ${ }^{*}$ J. O. Hill, ${ }^{*}$ B. R. Cullen, ${ }^{*}$ and N. Lane† \\ *Melbourne School of Land and Environment, University of Melbourne, Parkville, Victoria 3010, Australia \\ †Intelact Australia, PO Box 1120, Kingscliff, New South Wales 2487, Australia
}

\begin{abstract}
The irrigated dairy industry in southern Australia has experienced significant restrictions in irrigation water allocations since 2005, consistent with climate change impact predictions for the region. Simulation models of pasture growth (DairyMod), crop yield (Agricultural Production Systems Simulator, APSIM), and dairy system management and production (UDDER) were used in combination to investigate a range of forage options that may be capable of sustaining dairy business profitability under restricted water-allocation scenarios in northern Victoria, Australia. A total of 23 scenarios were simulated and compared with a base farm system (100\% of historical water allocations, grazed perennial ryegrass pasture with supplements; estimated operating surplus $\$ A 2,615 /$ ha at a milk price of $\$ A 4.14 / \mathrm{kg}$ of milk solids). Nine simulations explored the response of the base farm to changes in stocking rate or the implementation of a double cropping rotation on $30 \%$ of farm area, or both. Five simulations explored the extreme scenario of dairying without any irrigation water. Two general responses to water restrictions were investigated in a further 9 simulations. Annual ryegrass grazed pasture, complemented by a double cropping rotation (maize grown in summer for silage, followed by either brassica forage crop and annual ryegrass for silage in winter and spring) on $30 \%$ of farm area, led to an estimated operating surplus of $\$ \mathrm{~A} 1746 /$ ha at the same stocking rate as the base farm when calving was moved to autumn (instead of late winter, as in the base system). Estimated total irrigation water use was 2.7 ML/ha compared with 5.4 ML/ha for the base system. Summer-dormant perennial grass plus double cropping (30\% of farm area) lifted operating surplus by a further $\$$ A100/ha if associated with autumn calving (estimated total irrigation water use $3.1 \mathrm{ML} / \mathrm{ha}$ ). Large shifts in the forage base of dairy farms could sustain profitability in the face of lower, and fluctuating, water allocations.
\end{abstract}

Received October 31, 2011.

Accepted February 27, 2012.

${ }^{1}$ Corresponding author: David.Chapman@dairynz.co.nz
However, changes in other strategic management policies, notably calving date and stocking rate, would be required, and these systems would be more complex to manage. The adaptation scenarios that resulted in the highest estimated operating surplus were those where at least $10 \mathrm{t}$ of pasture or crop DM was grazed directly by cows per hectare per year, resulting in grazed pasture intake of at least $2 \mathrm{t}$ of $\mathrm{DM} / \mathrm{cow}$, and at least $60 \%$ of all homegrown feed that was consumed was grazed directly.

Key words: irrigated dairy system, pasture, forage crop, profitability

\section{INTRODUCTION}

Irrigated dairy in southeastern Australia is under pressure from several sources, including the effects of climate change and climate variability and competition for decreased water-storage volumes from other uses such as environmental flows. Climate change projections for southeastern Australia indicate warmer temperatures and an overall drier trend (CSIRO and BOM, 2007). Irrigated agriculture may experience large and rapid decreases in production due to the effect of decreased rainfall on runoff and irrigation water availability (Jones et al., 2001). Continuing drought and consequent decreases in rainfall runoff in irrigation storage catchments in the early years of this century saw substantial falls in irrigation allocations from 2006 to 2009 , to between 30 and $60 \%$ of historical entitlement (Figure 1).

The traditional pasture (perennial ryegrass, Lolium perenne L.)-based dairy production system developed in northern Victoria on the strength of full-irrigation water allocations does not appear to be sustainable when water allocations fall below historical levels. Perennial ryegrass is poorly adapted to dry soil conditions (Waller and Sale, 2001; Nie et al., 2004; Neal et al., 2009), and restricted irrigation allocations are insufficient to support survival of perennial ryegrass pastures over summer. This is driving rapid structural change and adaptation in the industry. A key question that arises from this situation is: how could dairy farming 


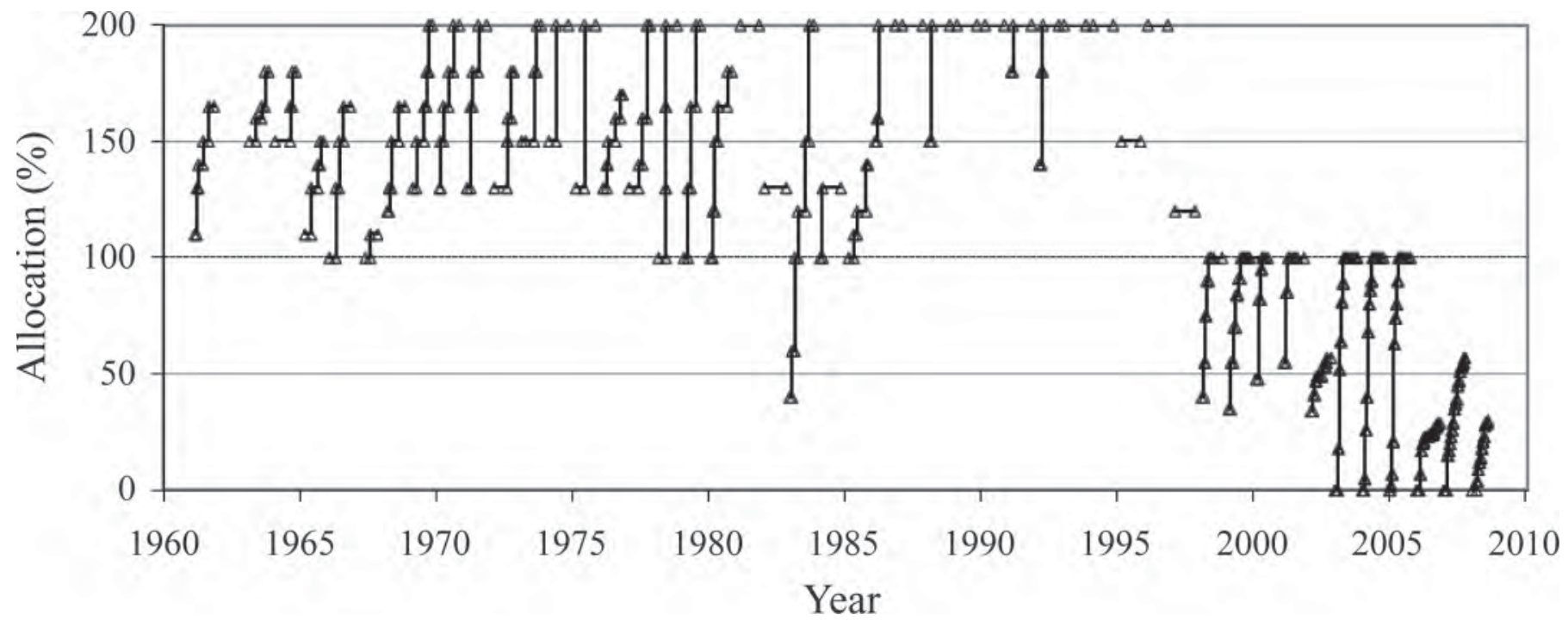

Figure 1. Annual water allocations (\% of water entitlement) to irrigators on the Goulburn-Murray water system (Goulburn-Murray Water, Tatura, Victoria, Australia) in northern Victoria and southern New South Wales, Australia, from 1960 to 2009. Data points within years show the progressive movement in allocation from the opening announcement for the forthcoming season through to the end of the irrigation season.

systems be adapted to sustain competitive operating profits when water allocations are restricted relative to historical levels?

A variety of management options are available to adapt dairy systems to decreased water allocations, and more diversity in the types of farming systems operating in the affected regions can be expected. For those businesses that remain forage based and use direct grazing of pasture and crops by animals to harvest most of the feed consumed, attention is likely to be directed toward changes in the forage base of the farm, including a variety of pasture and crop options. Pasture options include decreasing the proportion of area sown to perennials and using more winter annuals [e.g., annual pastures that require irrigation water only at the start (autumn) and end (mid-late spring) of their growing season]. Crop options include planting high-producing summer crops such as maize, where high tonnages of feed can be conserved as silage (Garcia et al., 2008). The combination of pasture and forage crops has several advantages over pasture-based systems: more DM produced per hectare than can be achieved with pasture only, decreasing the impact of seasonal deficits and the need for purchased supplements; more control of feed quality; and increased nitrogen and water-use efficiency (Garcia et al., 2008).

For irrigated dairy farms in northern Victoria, little is known of the production potential and management requirements of alternative homegrown forage systems, or how to design feedbase systems that incorporate other pasture species or crops, or both, that complement perennial ryegrass in their seasonal pattern of produc- tion and dietary quality. The aims of the modeling analysis presented here were to 1) investigate whether or not dairy farming systems in northern Victoria can be adapted so that they are capable of producing competitive operating profits with water allocations that are substantially less than historical allocations, at long-term average milk prices; and 2) for systems that show promise for sustaining competitive profitability, define the nature of the adaptation required, and some of the associated management policies.

\section{MATERIALS AND METHODS}

\section{Modeling Approach}

Models were used to simulate the physical characteristics, management policies, and production of an irrigated dairy farm at Dookie in northern Victoria, Australia $\left(-36.37^{\circ} \mathrm{N}, 145.70^{\circ} \mathrm{E}\right)$. The climate in this region is characterized by cool, wet winters and hot, dry summers. Under rain-fed conditions the pasture growing season is typically April to October but, if sufficient irrigation water is available, pasture can be grown year-round. The minimum mean monthly temperature occurs in July $\left(2.6^{\circ} \mathrm{C}\right)$, whereas the maximum mean monthly temperature occurs in February $\left(29.2^{\circ} \mathrm{C}\right.$; Figure 2).

The general modeling approach described in detail by Chapman et al. (2008) for estimating the physical production and economic performance of nonirrigated dairy systems in southern Victoria was also applied in this study. Briefly, 3 analytical tools were used: 
DairyMod (Johnson et al., 2008) and Agricultural Production Systems Simulator (APSIM; Keating et al., 2003) models to simulate growth of pastures and crops, respectively; and the UDDER (Larcombe, 1989) model to simulate management policies, production, and operating surplus of the dairy farm system. Outputs from DairyMod and APSIM were used as inputs to UDDER to describe the availability of pasture and other homegrown feeds.

Pasture Simulations. The DairyMod model was used to estimate mean monthly herbage accumulation rates for the following combinations of pasture species and irrigation strategies: perennial ryegrass, fully irrigated; Phalaris aquatica L. (Phalaris), partially irrigated; and annual ryegrass (Lolium multiflorum L.), partially irrigated or nonirrigated. Farmers currently use both perennial ryegrass and annual ryegrass. Phalaris is not currently used in the region. It was included here to test the potential of an alternative pasture species strategy for limited irrigation allocations. Phalaris is a perennial species; hence, it does not incur the yearly resowing costs associated with using annual ryegrass. It exhibits true summer dormancy (Laude, 1953; McWilliam, 1968), which could potentially be broken by the application of irrigation water in late summer and autumn (partial irrigation) after which winter and spring rainfall should be sufficient to sustain growth. Plants of this type, therefore, offer possible water use efficiency advantages, albeit at the cost of some loss of production over the summer months compared with fully irrigated perennial ryegrass. Parameter values used in the model to describe plant physiology and irrigation strategies are presented in Appendix Table A1, and parameters used to describe the soil profile and organic matter characteristics of the Dookie site are presented in Appendix Table A3.

The following daily weather data for the period 1961 to 2007 for the Dookie site were entered into the model for this purpose. The weather file comprised maximum and minimum temperature $\left({ }^{\circ} \mathrm{C}\right)$, rainfall $(\mathrm{mm})$, total global solar radiation $\left(\mathrm{MJ} / \mathrm{m}^{2}\right.$ per day), maximum and minimum relative humidity (\%), and vapor pressure $(\mathrm{kPa})$. The DairyMod model calculated estimated net daily herbage accumulation rate for each day of the simulation, based on the relationship between the level of availability of plant growth resources (temperature, plant-available soil water, and radiation) and plant physiology as defined for each species (Appendix Table A1). Daily values for net herbage accumulation rate were then averaged for each month, and these values were further averaged across the $47 \mathrm{yr}$ of each simulation to generate long-term mean monthly growth rates.

Crop Simulations. The yields of maize, brassica, and annual ryegrass crops were simulated (also for 1961

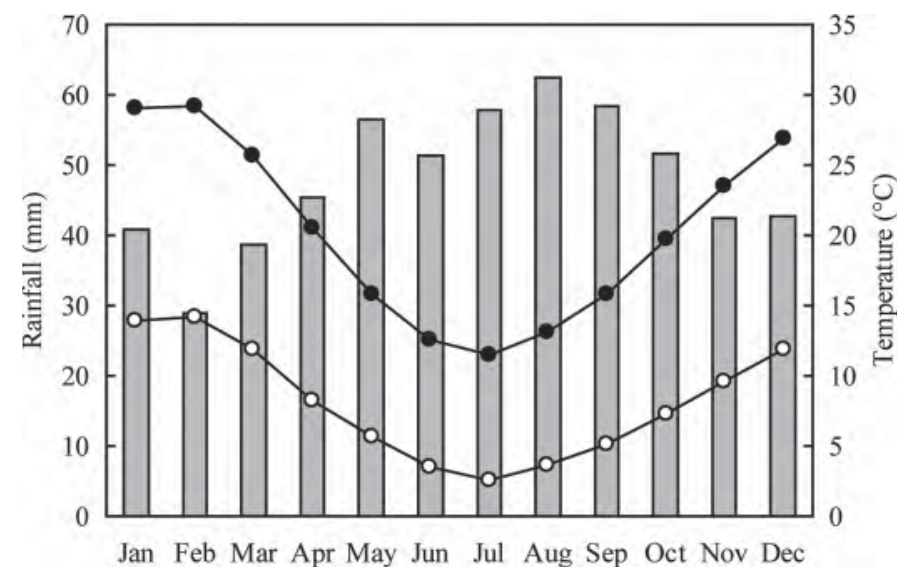

Figure 2. Average monthly rainfall (bars), maximum (filled circles) and minimum temperatures (open circles) based on daily data from 1961 to 2007 for Dookie in northern Victoria, Australia.

to 2007) using a configuration of APSIM version 7.0, including the modules of Maize, Canola, Annual Ryegrass, SoilWat2, SoilN 2 , SurfaceOM, and Manager. The APSIM modules were not available for forage brassica; therefore, APSIM-Canola was used to simulate forage brassica. The APSIM plant modules have been validated against a wide range of data sets, with the results indicating that the models adequately simulate crop growth (e.g., Sinclair and Muchow, 1995; Wilson et al., 1995; Robertson et al., 1999; Farré et al., 2001).

Parameter values used in the model to describe plant physiology and irrigation strategies for the crops are presented in Appendix Table A2, and parameters used to describe the soil profile and OM characteristics are presented in Appendix Table A3.

Dairy System Simulations. The UDDER model was used to estimate resultant milk production when animal management policies (particularly stocking rate and calving date) were adjusted to efficiently utilize the available feed. Homegrown forage supply (pasture and crop) was supplemented by feeds purchased from off-farm to optimize feeding in each scenario. The UDDER model simulates daily total energy intake by animals, and partitioning of energy to maintenance, body condition, and milk production. The UDDER model also calculates the operating surplus for the farm system (defined as the difference between total operating revenue and total operating expenses, not including financing costs and non-operating adjustments), using simulated inputs (purchased feed and fertilizer, among others) and per-cow and per-hectare costs that reflect operating expenses for dairy farms in the region. All simulations were based on a milk price of $\$ \mathrm{~A} 4.14$ per kilogram of milk solids (milk solids $=$ milk fat + milk protein), which approximates the long-term mean price 
Table 1. Comparison of reported and modeled [using the DairyMod (Johnson et al., 2008) and UDDER (Larcombe, 1989) models] physical and financial variables for the Dookie irrigated dairy farm in the 2004-2005 and 2005-2006 lactations, and benchmark data for farms in northern Victoria, Australia in 2005-2006 ranked among the top $10 \%$ of farms in the region for profitability ${ }^{1}$

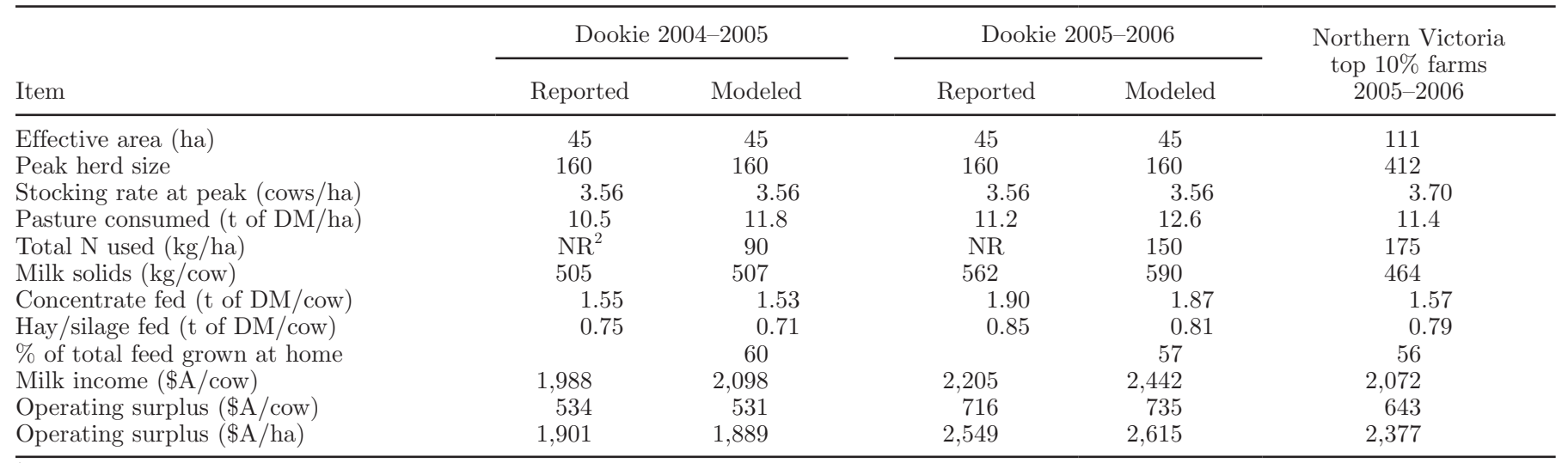

${ }^{1}$ Source: Red Sky Agribusiness (http://redskyagri.com.au). Milk price used in the model was $\$$ A4.14/kg of milk solids. Milk price used in the benchmark analysis was $\$ \mathrm{~A} 4.47 / \mathrm{kg}$ of milk solids.

${ }^{2} \mathrm{NR}=$ not reported.

received at the farm gate in Victoria. Parameter values used in UDDER to describe cows and herds, supplementary feeds, and prices and costs are presented in Appendix Table A4.

A base simulation was constructed using the commercial dairy farm operating at the Dookie campus of the University of Melbourne, in northern Victoria, in the 2004-2005 and 2005-2006 lactations. This farm has 45 ha of irrigated land, all of which was sown to perennial ryegrass pasture. The farm has a historical irrigation water entitlement of around $300 \mathrm{ML}$ (6.7 ML/ ha), and all of this was used in both years. Irrigation water was applied via bordercheck control to bays with a gradient of $0.125 \%$. The farm milked 160 HolsteinFriesian seasonally calving cows at peak. Calving began in August, and cows were milked for approximately 300 $\mathrm{d}$ before they were dried off and moved to an adjacent property for feeding in June and July.

Information on herd size, cow breed, management policies, physical production, and financial performance in the 2004-2005 and 2005-2006 lactations was used to construct the base simulation. Feeding policies were implemented in UDDER to match, as closely as possible, the total tonnage of purchased feeds consumed by the commercial herd while retaining cow BCS and average farm herbage mass (HM) within ranges considered to maximize productivity and profit for pasture-based systems in the region. Other management policies used to manipulate cow feed intakes, BCS, and HM were tactical nitrogen fertilizer applied monthly at varying rates (to boost the base pasture growth rates), area of land conserved for silage in spring (to control excess pasture HM and supply feed for periods of pasture deficit), and the length of the grazing rotation (to maximize pasture intake). The base simulation was accepted when a close level of agreement between model predictions and observed data was achieved (Table 1). All subsequent scenarios then used the base simulation as a starting point, and management adaptations were incorporated as described below to represent the different scenarios for irrigation water availability that were considered relevant to the objectives of the study.

\section{General Management Strategies}

With less water available for irrigation, the spatial and temporal pattern of water use for growing feed must change to maximize the amount of feed produced for each megaliter of water available. Strategies for achieving this include 1) growing $\mathrm{C}_{4}$ crops, such as maize, which are capable of growing high tonnages of forage during summer (Garcia et al., 2008; Greenwood et al., 2008); 2) using water to extend the normal winter-spring growing season resulting from the winterdominant rainfall pattern so that high-yielding, coolseason annuals such as annual ryegrass and brassica species can reach their yield potential; and 3) combinations of these in a double cropping rotation. Alternative forage systems were simulated based on the strategies described above for scenarios where irrigation water was restricted. Adjustments to strategic management policies (such as stocking rate and calving date), as well as tactical management policies (including feeding, $\mathrm{N}$ fertilizer use, and silage conservation, among others), were implemented to account for the different pattern of feed supply during the 10-mo lactation period. 


\section{Scenarios}

Twenty-four scenarios were analyzed and compared with the base system. These are summarized in Table 2 . The core factor underlying the structure of the simulations was the availability of irrigation water. Three levels of this factor where chosen: $100 \%$ of historical water allocation (for the Dookie farm, this is approximately 6.7 ML/ha, or $300 \mathrm{ML} / \mathrm{yr}$ ); zero irrigation water; and restricted annual allocation (notionally considered to fall within $30-60 \%$ of the historical full allocation). In Table 2, these are collated under group A, group B, and group C, respectively.

The $100 \%$ scenarios were included to help determine possible interactions between irrigation water availability and changes to strategic management policies. Because changes to stocking rate and use of double cropping were included in many of the restricted water scenarios, it is important to understand what effect these changes might have had on profitability if water availability were not restricted. The effect of changing stocking rate alone was investigated by running the base simulation with 175,190 , and 205 cows and adjusting tactical management policies as necessary to sustain BCS and HM profiles (group A-1, Table 2). The effect of introducing double cropping (see below for a more detailed description of the double-cropping practices simulated) was investigated by replacing perennial ryegrass pasture on $30 \%$ of the farm area with a maize crop grown in summer, which was then followed by either annual ryegrass or brassica during winter. The $30 \%$ figure was selected based on the irrigation allocation scenarios (see below) and published water use efficiency (WUE) values for maize (Edraki et al., 2003; Greenwood et al. 2008), brassica crops (Hirth et al. 2001), and annual ryegrass (Lawson et al., 2009). A simple spreadsheet calculation indicated that implementing a double crop rotation on about $30 \%$ of the irrigated land area would lead to optimal whole-farm WUE. A range of stocking rates was simulated (group A-2, Table 2) to determine the herd size that resulted in the most efficient conversion of the feed grown into farm operating surplus and, therefore, the total package of management changes that might be required to maximize returns from the change in farm forage base.

The zero water-allocation scenario was included to assess the extreme situation represented by for example, a farm where the decision had been made to sell all permanent water entitlements and operate at a low level of farming intensity. No such farms exist currently in northern Victoria, and our expectation was that this approach to dairying would not be profitable, even in the presence of substantial adjustments to strategic and tactical management policies. The scenario was included in this study for the purposes of completeness in the analysis of possible outcomes from changes to irrigation water availability in the region.

The restricted scenarios were chosen to represent conditions experienced by irrigators on the GoulburnMurray irrigation system (Goulburn-Murray Water, Tatura, Victoria, Australia) during the period 2006 to 2009 (Figure 1). The study sought to establish whether dairy systems could be successfully adapted to sustain profitability in the face of large shifts in the availability of the most important resource for dairying in the region. It was considered that sizeable shifts from the historical $100 \%$ allocation pattern would be more revealing in this regard than small shifts, which might effectively be dealt with by relatively minor adjustments while the fundamentals of the current farming system remain largely unchanged.

Two broad approaches were investigated for the restricted-water situation. The first was based solely on the use of annual species, both pasture species and crop species (group C-1, Table 2). The second was based on an alternative perennial grass species, Phalaris (group C-2, Table 2), which is winter active and summer dormant under southern Australian conditions (Oram and Culvenor 1994), whereas perennial ryegrass is not summer dormant.

Some differences existed in the structure of the C-1 and C-2 scenarios. First, spring calving was not simulated in the C-2 scenarios, as the principle of moving calving date to autumn to match the change in pasture growth curve was well demonstrated by results of the group B and group C-1 simulations; little additional new information was likely to emerge from a comparison of calving dates for the C-2 scenarios. Second, the calving date was moved forward by 1 mo compared with the C-1 water scenario, to begin in April, reflecting the prediction from DairyMod that pasture would be available from March onwards from the partially irrigated Phalaris (Figure 3).

The simulations all represented steady-state conditions, and did not take into account the transition from one system to another. They described what each system might look like, once in place. The 2 key indicators of system productivity and sustainability, BCS and HM, were used as yardsticks by which adjustments to management policies were implemented in response to each irrigation allocation scenario. We reasoned that, during the annual production cycle, efficient farmers would not allow either HM or BCS to drift to levels that threaten long-term pasture performance or cow production. Therefore, in all simulations, the effects of changing forage type, either with or without associated changes to stocking rate and calving date, were complemented by changes in tactical management policies so 
CHAPMAN ET AL.

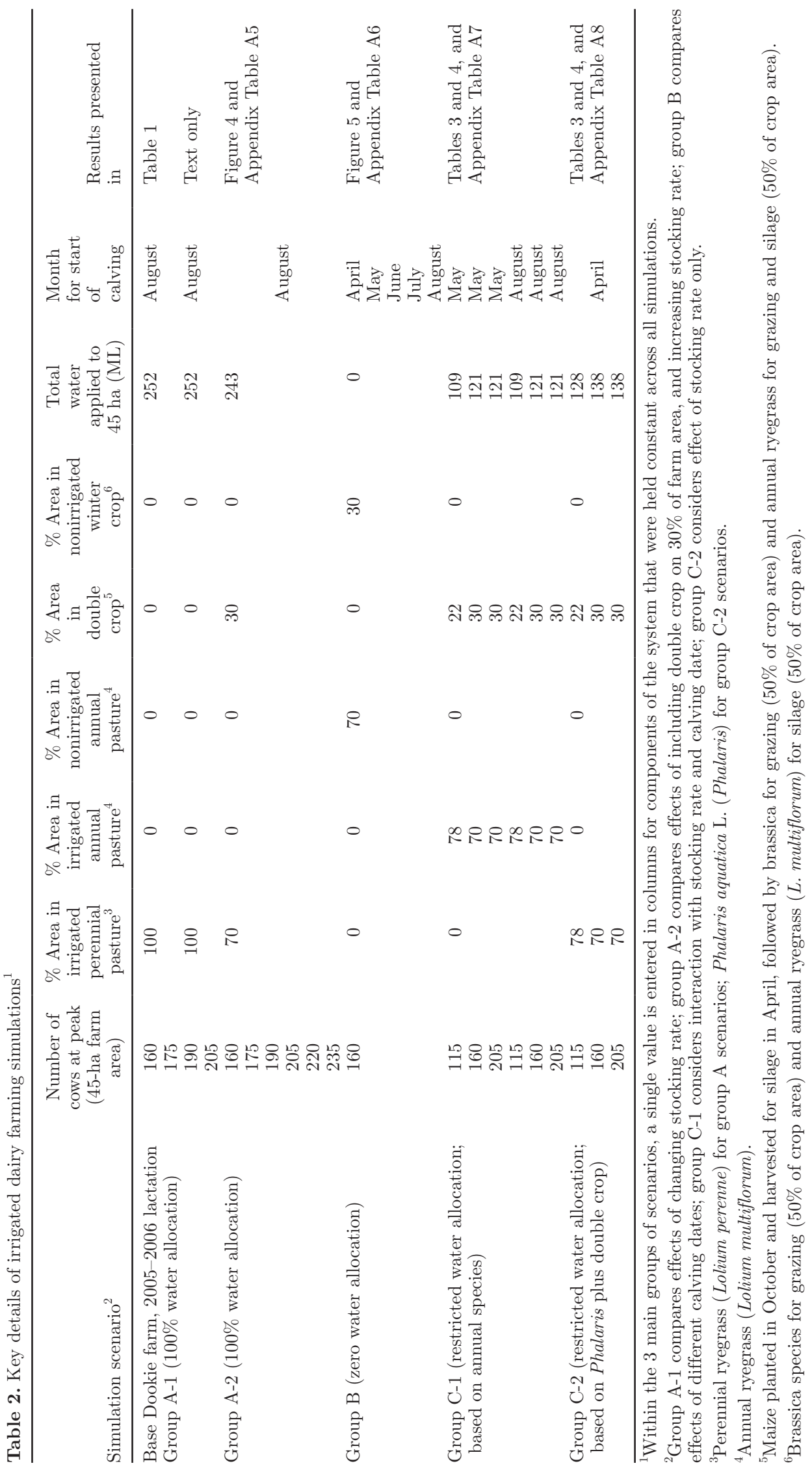



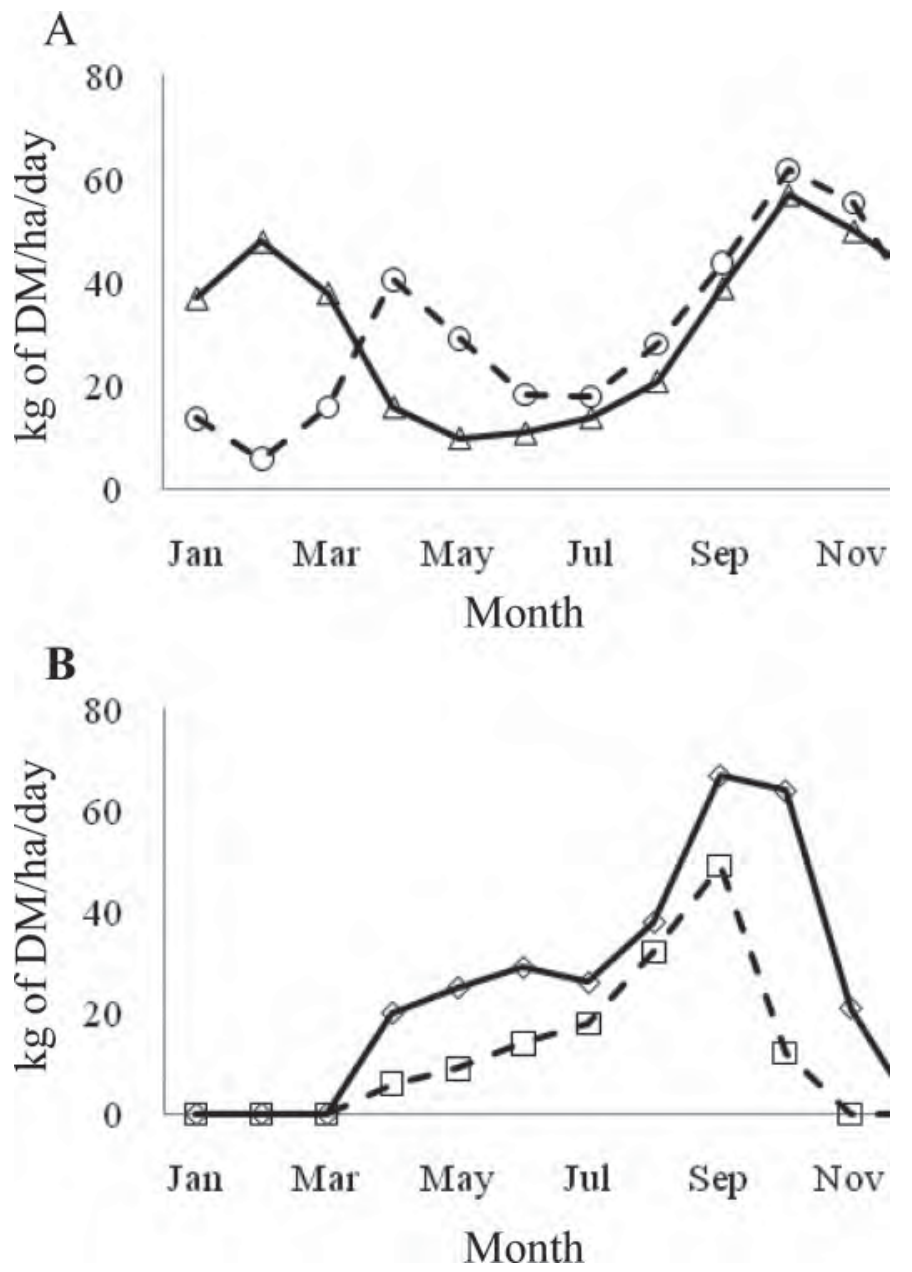

Figure 3. Pasture growth curves (mean monthly herbage accumulation rate, $\mathrm{kg}$ of $\mathrm{DM} /$ ha per day) simulated in the DairyMod (Johnson et al., 2008) model for A) perennial pastures: fully irrigated perennial ryegrass (open triangles with solid line) and partially irrigated Phalaris aquatica L. (Phalaris; open circles with dashed line) and B) annual pastures: partially irrigated annual ryegrass (open diamonds with solid line) and nonirrigated annual ryegrass (open squares with dashed line).

that the mean annual BCS and HM curves matched as closely as possible the curves for the base simulation.

The simulation procedure involved manipulating feeding policies, grazing management, $\mathrm{N}$ fertilizer inputs and pasture silage conservation practices within the 10-d windows available in UDDER to maximize profit within the constraints imposed by the HM and BCS curves. This procedure meant that milk production (per cow and per hectare) and farm operating surplus were outputs of the simulation. These were the key variables used to assess the potential for sustaining dairy production and profit under conditions of markedly changed irrigation water availability.

\section{Forage Species}

Perennial Ryegrass Pasture. The predicted (from DairyMod) mean total annual herbage accumulation for perennial ryegrass pasture with $100 \%$ water allocation was $15,660 \mathrm{~kg}$ of DM/ha, distributed monthly, as shown in Figure 3A. The mean total irrigation water applied in the model was $559 \mathrm{~mm} / \mathrm{yr}$, which supplemented a mean of $568 \mathrm{~mm}$ of rainfall/yr (falling dominantly in winter and spring). Estimated WUE of the simulated perennial ryegrass pasture was, therefore, $14.0 \mathrm{~kg}$ of $\mathrm{DM} / \mathrm{mm}$ of total water (range 10.1-20.0). Additional herbage accumulation was generated in UDDER as a result of $\mathrm{N}$ fertilizer addition, which was one of the suites of tactical management tools used to achieve sustainable levels of farm performance. Nitrogen was added at rates of 30 to $40 \mathrm{~kg}$ of N/ha per application, as required to maintain HM within the target range, as explained above. A nitrogen response efficiency of $10 \mathrm{~kg}$ of DM grown per kilogram of $\mathrm{N}$ applied was assumed for all applications (Mundy, 1999). Total amounts of $\mathrm{N}$ applied to pasture as fertilizer are reported in Appendices Tables A5, A6, A7, and A8.

Annual Ryegrass (Used for Grazing). The predicted (from DairyMod) mean total annual herbage accumulation for grazed annual ryegrass with restricted irrigation was $11,710 \mathrm{~kg}$ of $\mathrm{DM} / \mathrm{ha}$, distributed monthly as shown in Figure 3B. The mean total irrigation water applied was $170 \mathrm{~mm} / \mathrm{yr}$, and total WUE was estimated to be $16.4 \mathrm{~kg}$ of $\mathrm{DM} / \mathrm{mm}$ of total water (range 9.6-26.9). For nonirrigated annual ryegrass, the equivalent figures were unadjusted mean total annual herbage accumulation $5,230 \mathrm{~kg}$ of $\mathrm{DM} /$ ha (Figure $3 \mathrm{~B}$ ); mean WUE $9.6 \mathrm{~kg}$ of DM/mm (range 5.3-14.2).

Phalaris. Irrigation water was applied as surface water at rates of $30 \mathrm{~mm}$ every $10 \mathrm{~d}$ from March 1 to April 15, and the pasture was watered to $100 \%$ of field capacity (FC) whenever soil water availability fell to $75 \%$ of FC, from September 1 to November 15. Mean total irrigation water applied was $225 \mathrm{~mm} / \mathrm{yr}$. Analysis of water balance output information from DairyMod revealed that, under this irrigation management regimen, no irrigation water was necessary in the spring period (i.e., plant-available water did not reach the $75 \%$ FC trigger) in 28 of the $47 \mathrm{yr}$ simulated. Irrigation inputs of between 1 and $100 \mathrm{~mm}$ were necessary in 4 of the $47 \mathrm{yr}$, between 101 and $200 \mathrm{~mm}$ in $4 \mathrm{yr}$, between 201 and $300 \mathrm{~mm}$ in $3 \mathrm{yr}$, and $>301 \mathrm{~mm}$ in $8 \mathrm{yr}$.

The predicted (from DairyMod) mean total annual herbage accumulation for Phalaris pasture under these conditions was $14,700 \mathrm{~kg}$ of DM/ha distributed seasonally, as shown in Figure 3A, with a mean WUE of 19.1 $\mathrm{kg}$ of $\mathrm{DM} / \mathrm{mm}$ (range 11.5-30.3). 
Double Cropping. Double cropping refers to maize grown for silage with irrigation (October-April) on 30\% of the total available irrigated land (13.5 ha), followed (on the same area of land) by brassica for grazing ( $50 \%$ of maize area, or $6.75 \mathrm{ha}$ ) and annual ryegrass for silage (50\% maize area, 6.75 ha) grown mainly with winter/ spring rainfall.

The predicted (from APSIM) mean annual herbage mass available at harvest for the maize crop was 19 $\mathrm{t}$ of $\mathrm{DM} /$ ha. This value was discounted for losses in total DM during ensiling (10\%; Mickan et al., 2003) and losses incurred when feeding (assumed to be 15\%; Stockdale, 2010). Hence, the amount of maize consumed by dairy cows was equivalent to $14 \mathrm{t}$ of $\mathrm{DM} /$ ha from the cropped area, or a total of $190 \mathrm{t}$ of DM consumed. The mean total irrigation water applied was $437 \mathrm{~mm} / \mathrm{yr}$, which supplemented a mean of $190 \mathrm{~mm}$ of rainfall during the cropping period (sowing to harvest). Therefore, mean predicted WUE was $30 \mathrm{~kg}$ of $\mathrm{DM} / \mathrm{mm}$ of total water (range 21-39).

For the brassica crop, the predicted (from APSIM) mean annual herbage mass available at harvest was 8.5 $\mathrm{t}$ of $\mathrm{DM} / \mathrm{ha}$. This value was discounted for wastage during grazing (for example, due to wet soils during winter when the crop was fed), leading to an assumed $6 \mathrm{t}$ of $\mathrm{DM} /$ ha of feed consumed from the cropped area, or a total of $41 \mathrm{t}$ of DM consumed. The mean total irrigation water applied in APSIM to grow the crop was $54 \mathrm{~mm} / \mathrm{yr}$, which supplemented a mean of $340 \mathrm{~mm}$ of rainfall during the cropping period (sowing to grazing). Therefore, the mean predicted WUE was $23 \mathrm{~kg}$ of DM/ $\mathrm{mm}$ of total water (range 13-42).

Where annual ryegrass was grown as a crop following the maize (for silage conservation), the predicted (from APSIM) mean annual herbage mass available at harvest was $12 \mathrm{t}$ of DM/ha, which was discounted for wastage during harvest, conservation, and feeding to yield $9 \mathrm{t}$ of $\mathrm{DM} /$ ha of feed consumed from the cropped area, or a total of $59 \mathrm{t}$ of DM consumed. The mean total irrigation water applied in APSIM to grow the crop was $67 \mathrm{~mm} / \mathrm{yr}$, which supplemented a mean of 340 $\mathrm{mm}$ of rainfall during the cropping period (sowing to harvest). Therefore, the mean predicted WUE was 31 $\mathrm{kg}$ of $\mathrm{DM} / \mathrm{mm}$ of total water (range 19-51).

\section{RESULTS}

\section{Base Farm Simulations (Appendix Table A5)}

This section presents an analysis of the base Dookie dairy farm, to determine 1) how closely the model predictions agree with reported information for both the case business, and for farm businesses in the region;
2) how responsive the base system is to changes in stocking rate, in the absence of any changes to the forage base; and 3) how responsive the base system is to incorporation of double cropping into the forage base of the farm. In the latter instance, it was necessary to also adjust stocking rate to utilize feed effectively. All of the simulations reported in this section were conducted assuming $100 \%$ of water right was allocated to the farm.

\section{Modeled Versus Reported Farm Performance}

A comparison of modeled versus reported values for key physical and financial variables of the Dookie dairy farm system is presented in Table 1. Effective farm area and herd size (and hence, stocking rate) were fixed inputs to the model. The amounts of concentrate and hay or silage fed per cow were constrained so that total annual estimated feeding levels were close to those reported in both years. Pasture consumption, milk production, milk income, and operating surplus are all emergent properties of the model, and of the greatest relevance when comparing model predictions with reported performance. There is reasonable agreement between modeled and reported values for these variables. Modeled values exceeded reported values in all but one instance where the emergent properties were compared, with the difference between the 2 values falling in the range +0.4 to $+19 \%$. Considering the many errors that exist in measuring and modeling pasture consumption and the variation observed among financial management tools regarding which costs and prices are included in analyzing farm operating surplus (and how those costs and prices are calculated), this level of agreement confirms that the model provides a realistic simulation of farm performance for the base system.

Benchmark database information provides an opportunity for further comparison of model predictions versus observed farm performance. Table 1 includes information for farms ranked (on the basis of profitability) in the top $10 \%$ of farm businesses in northern Victoria in 2005-2006, a year when $100 \%$ water allocations were available to farms in the Goulburn Murray irrigation systems. These data indicate that the Dookie farm performed at a level consistent with top $10 \%$ performance in the region. Compared with the benchmark information, the modeled Dookie system in 2005-2006 was characterized by slightly higher pasture consumption, slightly lower $\mathrm{N}$ fertilizer use, much higher per animal production, and moderately higher concentrate feeding (Table 1). The amount of forage (silage and hay) supplement fed, and the percentage of total feed consumed that was grown at home, was very similar for the modeled and benchmark systems. 


\section{Response of the Base Farm System to Stocking Rate}

The simulated base farm system was relatively unresponsive to increases in stocking rate. Estimated operating surplus per hectare increased from \$A2615 at 3.56 cows $/$ ha to $\$ \mathrm{~A} 2641 /$ ha at 3.89 cows $/$ ha, then decreased to $\$ \mathrm{~A} 2586$ and $\$ \mathrm{~A} 2554$ at 4.22 and 4.56 cows/ha, respectively. Progressively adding cows to the simulation herd size increased pasture consumption per hectare steadily, up to $13.6 \mathrm{t}$ of $\mathrm{DM} /$ ha at 4.56 ha, but this required additional $\mathrm{N}$ fertilizer (up to $278 \mathrm{~kg}$ of $\mathrm{N} /$ ha at 4.56 cows/ha) to maintain average herbage mass within acceptable limits. In the simulation of the highest stocking rate, it was necessary to purchase an additional $100 \mathrm{t}$ of DM (total for farm) as good-quality hay to maintain cow body condition and production. At 4.56 cows/ha, the estimated percentage of total feed supplied from homegrown sources fell to $50 \%$, compared with almost $57 \%$ in the base simulation. These additional inputs eroded the gains from extra milk revenue.

\section{Response of the Base Farm System to Double Cropping (Figure 4; Appendix Table A5)}

When $30 \%$ of the effective area of the case farm was converted to a double-crop rotation of maize grown through summer (for silage), followed in winter by either a brassica crop (grazed) or annual ryegrass (for silage), the estimated farm operating surplus decreased substantially compared with the base simulation. At the same stocking rate $(3.56$ cows $/$ ha, peak herd size $=$ 160 cows), estimated operating surplus was $\$ A 1625 /$ ha for double crop (Figure 4; Appendix Table A5) versus $\$ \mathrm{~A} 2,615 /$ ha for the base system (Table 2; Appendix Table A5). While a higher percentage of total feed came from homegrown sources in the double-crop simulation (66 vs. 57\%; see Appendix Table A5 for detailed results from the double-crop simulations), a surplus of homegrown maize silage remained at the end of the lactation, leading to inefficient conversion of feed grown into milk. This was addressed by increasing stocking rate, which resulted in higher operating surplus per hectare up to around 4.5 cows per ha, after which operating surplus decreased (Figure 4). Total homegrown forage consumption reached a maximum of $16.5 \mathrm{t}$ of DM/ha at 4.56 cows/ha and then plateaued (Appendix Table A5), after which the percentage of total feed required supplied by homegrown sources decreased, and purchased feed costs increased. A stocking rate of 4.56 cows/ha (peak herd size $=205$ cows) appeared to optimize the balance between feed demand and feed supply from homegrown sources, and produced the highest apparent operating surplus (Appendix Table A5). However, this

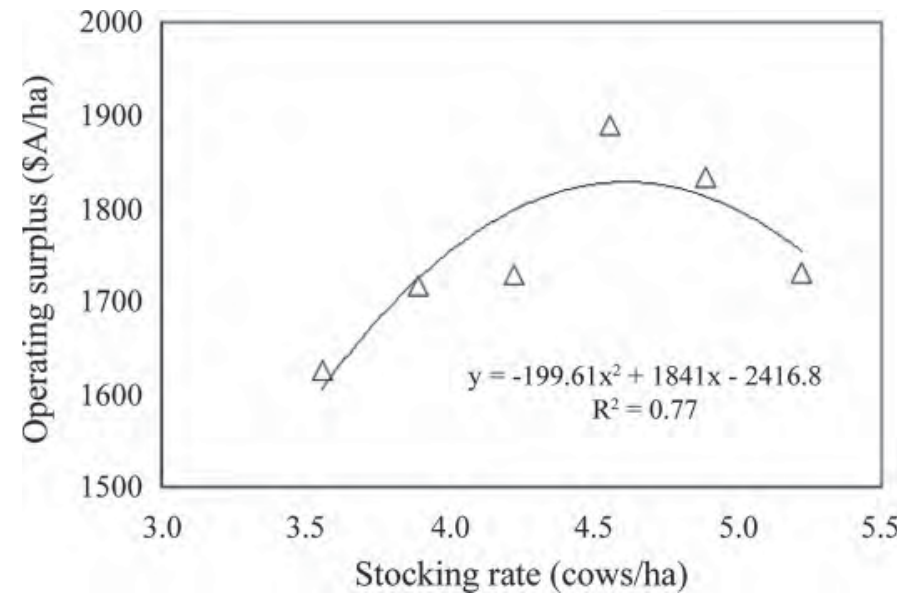

Figure 4. One hundred percent water allocation. Estimated operating surplus per hectare for different stocking rates applied to a dairy production system in northern Victoria, Australia, with $30 \%$ of farm area used for a double-cropping rotation.

operating result was still more than $\$ \mathrm{~A} 700 /$ ha less than the base system stocked at 3.56 cows/ha.

\section{Zero-Water Scenarios (Appendix Table A6)}

Simulated operating surplus collapsed to negative or very low positive values when dairying was simulated with no irrigation (Figure 5; Appendix Table A6). Changing the month in which calving started did influence operating surplus, with earlier calving (April or, especially, May) superior to later calving (Figure $5)$. This was the result of greater pasture consumption in early lactation when calving started in April or May, which improved dietary quality and enabled better overall feeding, combined with a higher milk price because more milk was produced in winter attracting a seasonal price incentive (Appendix Table A6). However, operating surplus was minimal even with these advantages.

\section{Restricted-Water Scenarios (Appendix Tables A7 and A8)}

The simulated milk production and operating surplus for the 6 scenarios based entirely on annual pasture and crop species are shown in Table 3. As expected, milk solids production was greater at higher stocking rates. The simulated operating surplus was similar at the 2 higher stocking rate scenarios within each of the calving policies, and both clearly resulted in higher profitability compared with the lowest stocking rate.

There was a clear effect of time of calving on the operating surplus. Profit was greater when the start 
Table 3. Restricted-water scenarios: simulated milk production (kg of milk solids/ha) and operating surplus (OS; $\$$ A/ha) of dairy systems operating at different stocking rates, with calving starting either in May or August for the annual pasture/crop scenario ${ }^{1}$

\begin{tabular}{|c|c|c|c|c|c|c|}
\hline Scenario & \multicolumn{6}{|c|}{ Stocking rate } \\
\hline \multicolumn{7}{|l|}{ Annual pasture/crop } \\
\hline May calving & 1,488 & 1,207 & 2,041 & 1,684 & 2,502 & 1,746 \\
\hline August calving & 1,459 & 949 & 1,990 & 1,055 & 2,415 & 1,001 \\
\hline
\end{tabular}

${ }^{1}$ The month for start of calving for the Phalaris aquatica L. (Phalaris) plus double-crop water scenario was April.

of calving was moved to May 1, compared with the August 1 start date used in the base farm system simulations, irrespective of stocking rate. Milk solids production tended to be higher for May calving than for August calving, but this difference was small and does not explain the difference in operating surplus.

Simulations based on May calving consistently resulted in higher direct-grazed intake of pasture per cow than August-calving simulations (Table 4). There was no difference in the contribution of all homegrown forage sources to total feed consumed, but the proportion of homegrown forage consumed that was grazed directly was higher for May calving than August calving, especially at the 2 higher stocking rates (Table 4). Less $\mathrm{N}$ fertilizer was required to boost pasture growth for feeding and to maintain average farm herbage mass in the May calving simulations compared with the August calving simulations, which would have resulted in lower costs of production for the former.

All of the simulations based on Phalaris pastures plus double cropping resulted in higher operating surplus

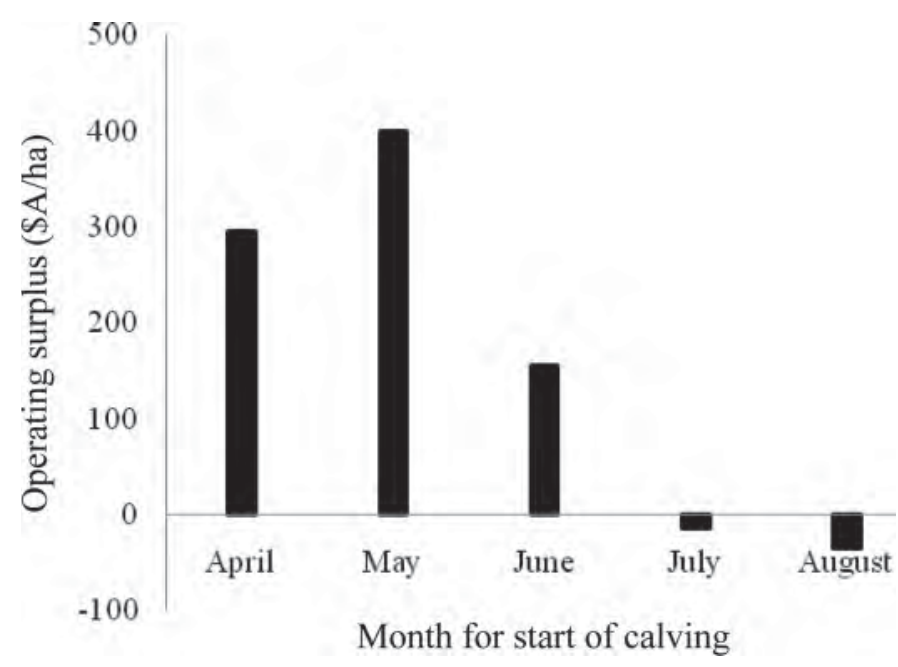

Figure 5. Zero water allocation. Estimated operating surplus per hectare for different calving dates applied to a dairy production system in northern Victoria, Australia, with no irrigation water entitlement. than the equivalent (May-calving) annual pasture/ crop scenarios (Table 3). Estimated operating surplus increased with stocking rate, as was the case for the annual pasture/crop scenarios. The strategy used for the Phalaris plus double-crop scenario allowed higher percow intakes of grazed pasture and resulted in a markedly higher proportion of the homegrown feed being consumed directly by grazing (Table 4 ). These factors would have decreased costs of production compared with the annual pasture/crop scenarios, and helped improve operating surplus.

\section{Trends and Relationships}

The estimated milk production and operating surplus resulting from all the scenarios analyzed are presented in Figure 6 relative to the mean total amount of irrigation water applied per hectare. A clear trend exists toward higher operating surplus with higher water allocation (best described by a second-order polynomial: $\left.\mathrm{y}=-50.874 \mathrm{x}^{2}+597.58 \mathrm{x}+153.2, \mathrm{R}^{2}=0.85\right)$, but no trend in milk solids production with irrigation allocation. Hence, operating surplus and milk production were not related under the management policies implemented in these scenarios. Of all the factors simulated in these analyses, the amount of pasture harvested directly by grazing per hectare per year showed the closest relationship to operating surplus (Figure 7A). Pasture consumed per cow was also related to operating surplus (Figure 7B). The amount of homegrown forage consumed, expressed as a percentage of total feed consumed on the farm, was not closely related to operating surplus (Figure $7 \mathrm{C}$ ). The base farm simulations, which resulted in the highest estimated operating surplus, achieved $12.5 \mathrm{t}$ of pasture DM grazed directly by cows per hectare per year, resulting in grazed pasture intake of at least $3 \mathrm{t}$ of pasture $\mathrm{DM} /$ cow. No other feed was grown on farm that required conservation and feeding out (i.e., close to $100 \%$ of all homegrown feed consumed on farm was grazed directly; Figure 7D). Among the restricted irrigation scenarios, the closest 
match to those performance levels came from systems where around $10 \mathrm{t}$ of pasture DM was grazed directly per hectare, cow intake of grazed pasture was 2.0 to $2.5 \mathrm{t}$ of $\mathrm{DM} / \mathrm{yr}$, and $60 \%$ of homegrown feed that was consumed was grazed directly.

\section{DISCUSSION}

\section{Profitability of Dairying}

Since irrigation development opened the way for dairying to begin in northern Victoria in the 1950s (Godbold, 1989), dairy farming systems have evolved by exploiting the availability of sufficient water to fully irrigate perennial pastures from late spring to mid autumn. This resulted in high levels of profitability because farmers were able to operate with low feed costs. The resultant pasture growth curve (Figure 3A) aligned well with the feed demand pattern of a herd calving mainly in late winter or early spring. Grain concentrate complemented the pasture base by increasing dietary energy density, and was readily available from regional sources at moderate cost relative to the long-term milk price. The robustness of this system is well illustrated by the predicted negative impact of incorporating double cropping on $30 \%$ of total farm area on the operating surplus of the base farm (Appendix Table A5). The increase in consumption of homegrown forage resulting from the replacement of pasture with crop failed to compensate for the additional costs of establishing, harvesting, conserving, and feeding the bulk of forage produced from the maize and annual ryegrass forages included in the double-crop rotation.

With these advantages, northern Victorian farm businesses were typically among the most profitable in the Australian dairy industry during the 1990s (Martin et al. 2000). However, the settings for dairy production in the region changed markedly from 2002, when the on-farm impacts of decreased water allocations were first experienced (Figure 1). The outcome of decreased water allocation in the 2006-2007 season (Figure 1) was a sharp drop in average farm profitability in northern Victoria ( $-\$ A 330 /$ ha operating profit, compared with $\$ A 1,169 /$ ha operating profit in 2005-2006, with milk price $\$ \mathrm{~A} 4.23$ and $\$ \mathrm{~A} 4.40$ for the respective years; source: Red Sky Agribusiness northern Victoria dairy benchmarks 2006-2008, http://redskyagri.com.au). This has raised many questions regarding what types of farming systems could be sustainable in a future where climate change projections indicate markedly lower volumes of rainfall run-off in irrigation storage catchments (Jones et al., 2001; Jones and Durack, 2005; Chiew et al., 2008). 


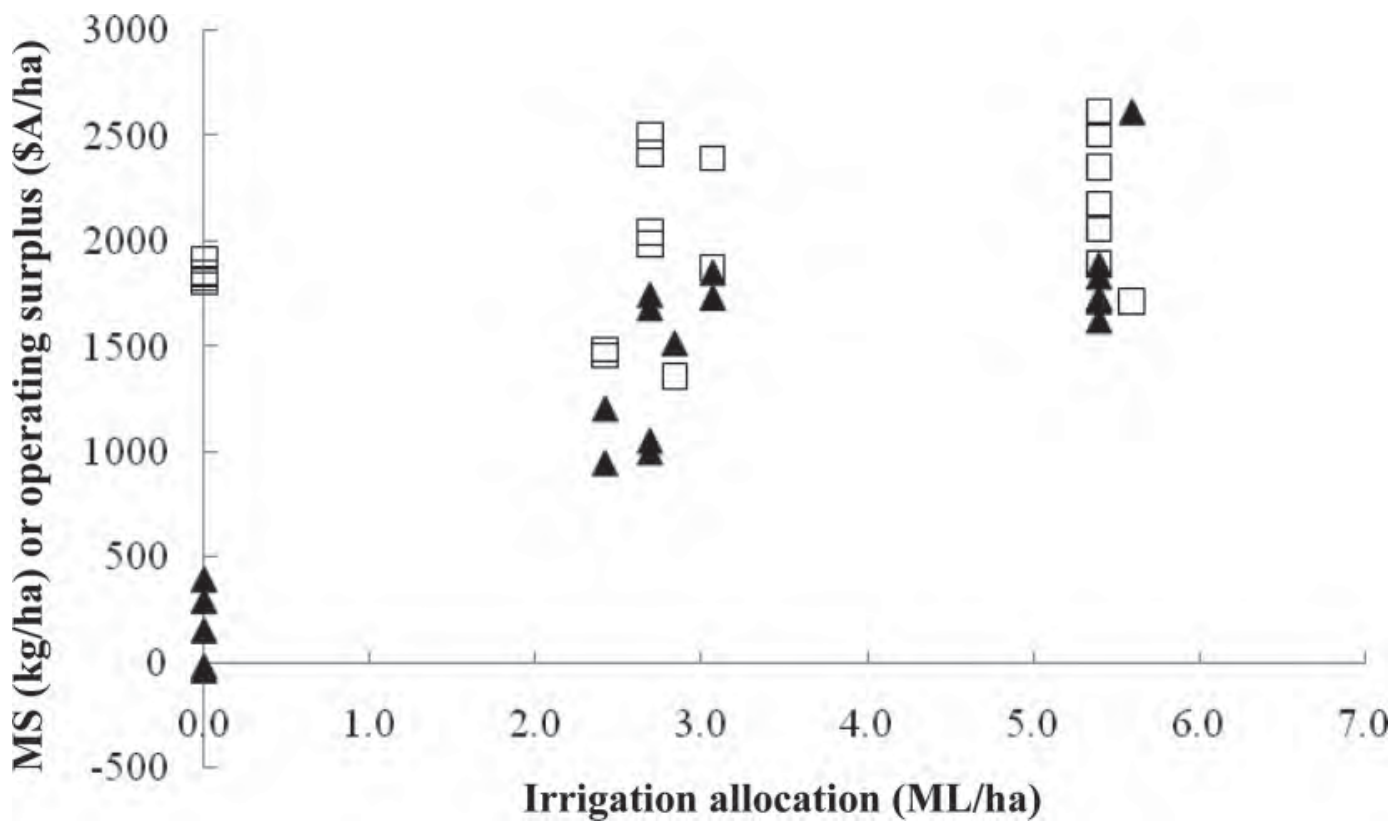

Figure 6. All scenarios. Simulated milk solids (MS) production $(\square)$ and operating surplus $(\boldsymbol{\Lambda})$ per hectare for different irrigation allocation scenarios applied to a dairy production system in northern Victoria, Australia.

The scenarios analyzed in this study confirm that dairy farming without irrigation water is not economically viable, even with changes to stocking rate and calving date (Figure 5; Appendix Table A5). They also show that substantial reductions in irrigation water allocations below the historical trend greatly affect the operating surplus of farm businesses in northern Victoria (Figure 6). Farmers in the region have experienced this directly in recent years as the effects of below-average annual rainfall from 1997 onwards have decreased irrigation storage inflows and, hence, water allocations to irrigators. Decreased water allocation has forced farmers in northern Victoria to adapt their systems, because there has been insufficient water to sustain the growth of perennial ryegrass pasture year-round. The incorporation of annual forage species, either annual ryegrasses or forage crops such as maize, has been a common adaptation. Winter annual grasses and crops utilize mainly winter rainfall for growth, although irrigation is required in late summer and early autumn to ensure timely germination and early growth of the pasture. Summer annual crops such as maize can be grown on a restricted part of the milking platform area and fully watered with the water available to create a bulk feed source to help fill the feed gap created by loss of grazed pasture. Tactical use of available irrigation water combined with reasonably reliable (though relatively low) winter rainfall offers opportunities for double cropping [i.e., winter crop (or annual pasture) following summer crop on the same area of land] to increase total forage DM grown on a proportion of total farm area.

These were the major adaptations incorporated within the annual pasture/crop scenarios simulated here. They led to estimated operating surpluses of $>\$ A 1,500 /$ ha with a stocking rate of more than 3.5 cows/ha and when calving was moved to autumn rather than late winter to better match the altered seasonal pattern of availability of grazed forage (Figure 3B). The package of double cropping, change in calving date, adjustment to stocking rate, and importation of more purchased feed could sustain levels of profitability in northern Victoria that are comparable to other dairy regions in the State that are not reliant on irrigation. For example, farms in southwest Victoria and Gippsland falling in the top $10 \%$ of all dairy businesses in these regions (based on return on assets) achieved $\$ \mathrm{~A} 1,588 / \mathrm{ha}$ and $\$ \mathrm{~A} 2,089$ / ha operating profit, respectively, in 2009-2010, with respective milk prices of $\$ \mathrm{~A} 4.81$ and $\$ \mathrm{~A} 5.09 / \mathrm{kg}$ of milk solids (source: source Red Sky Agribusiness Gippsland and southwest Victoria benchmarks 2008-2010; http:// redskyagri.com.au). However, these changes lead to a substantially different system of farming compared with the traditional approach, with additional management requirements and a different risk profile. The associated management requirements and risks of the system, or variations of it, have not yet been addressed in systemscale research in the region; there appears to be a case for conducting such research to support industry adaptation during a period of change. Such research should 


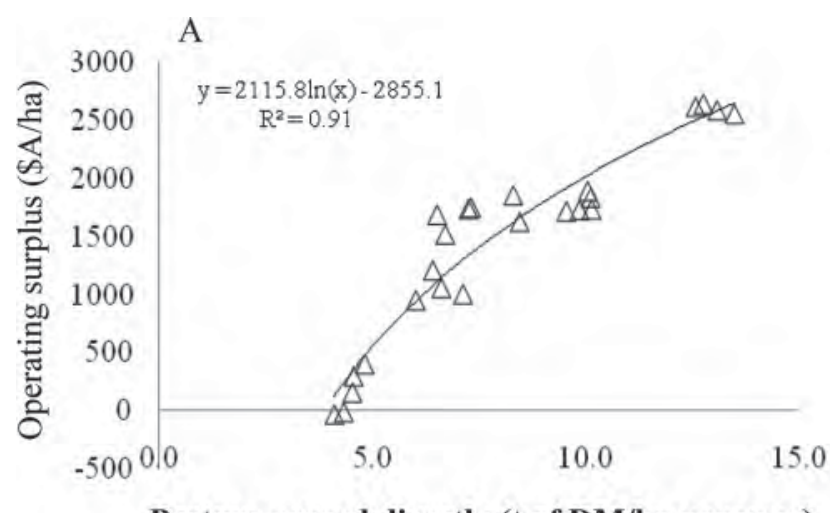

Pasture grazed directly ( $t$ of DM/ha per year)

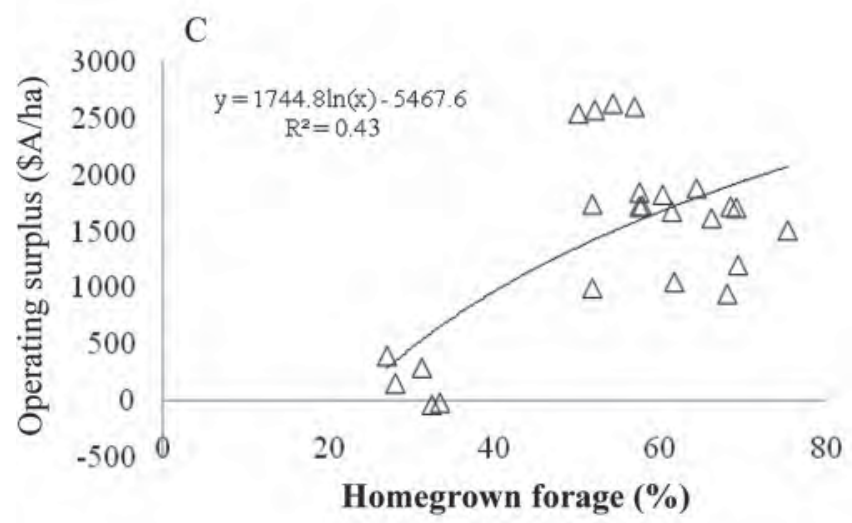

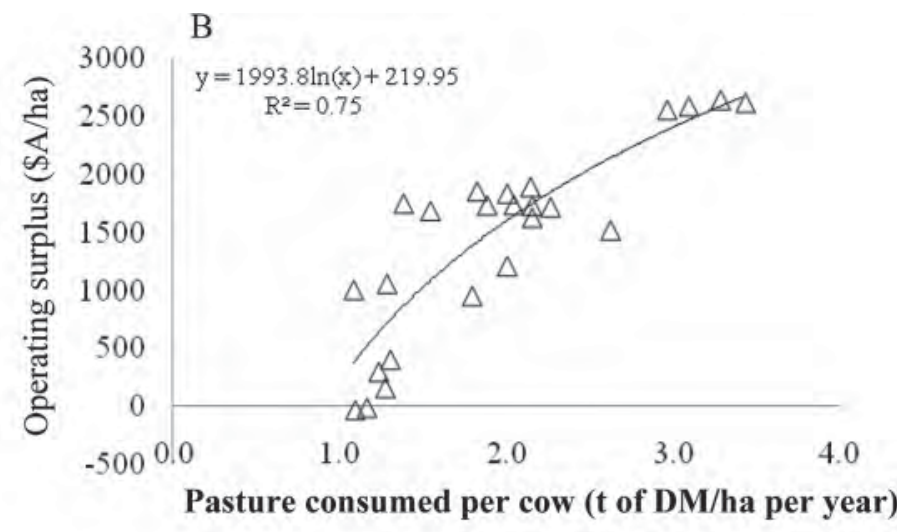

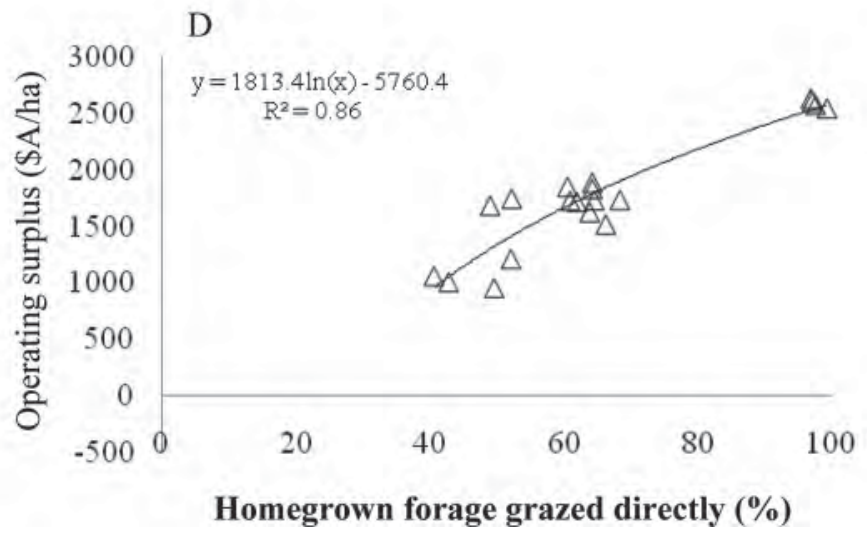

Figure 7. All scenarios. Relationships between farm operating surplus and A) total annual pasture consumption per hectare; B) pasture consumed per cow; C) homegrown forage consumed as a percentage of total feed consumed; and D) the percentage of homegrown feed consumed that was grazed directly, for different irrigation allocation scenarios applied to a dairy production system in northern Victoria, Australia.

also address the flexibility available within the system design for dealing with between-year variability in the amount of water allocated to irrigators (Figure 1). Although this variability may be addressed effectively by changes to water management policy that allow farmers to, for example, trade water entitlements or carryover entitlements between years, flexibility behind the farm gate is also desirable for coping with large shifts in total resource availability for dairy production.

A review of the results of all simulations reveals some key principles from which further analysis of system adaptation options can be conducted. The relationships in Figure 7 illustrate the keys to securing profitability: grazed pasture, or other homegrown forages that can be grazed, is paramount, both in terms of the absolute amount harvested and the proportion that grazed pasture/forage comprises of the cow diet. This was the strength of the fully irrigated perennial ryegrass system upon which industry profitability was historically based. The question is how can this key performance indicator be maximized when water availability is substantially reduced? The failure of perennial ryegrass plant populations to survive in environments with long, hot, and dry summers (Waller and Sale, 2001; Nie et al., 2004; Neal et al., 2009) rules out the continued use of this species when irrigation cannot be implemented fully. For these reasons, we did not simulate the growth of partially irrigated perennial ryegrass pasture in DairyMod, as the simulation model does not explicitly include plant mortality (Johnson et al., 2008). It, therefore, overestimates pasture recovery following severe water stress.

An alternative strategy implemented in the Phalaris plus double-cropping scenarios was to include a perennial grass species that possesses true summer, or endogenous, dormancy (Volaire et al., 1998a,b; Norton et al., 2008) that is broken by quite precise signals related to water availability after the summer dry period (Thomas, 1991; Norton et al., 2008). The notion here is that new season pasture growth could be switched on by tactical irrigation in late summer or early autumn, 
and maintained into late spring on an as-needed basis also by irrigation. Phalaris aquatica was used here to represent this plant ideotype in DairyMod. The inclusion of this pasture type moved the key indicators of direct pasture harvest in the right direction. For example, at 3.56 cows/ha and calving in autumn, estimated grazed pasture intake was $2.04 \mathrm{t}$ of $\mathrm{DM} /$ cow per year for the Phalaris plus double-cropping simulation versus $1.54 \mathrm{t}$ of DM/cow per year for the annual pasture/crop scenario, whereas the proportion of total homegrown forage consumed that was grazed directly was 0.684 and 0.491 for the respective scenarios (Table 4).

These levels of performance (Table 3) still fall well short of the base simulation with $100 \%$ water (Appendix Table A5). However, the estimated operating surplus for the Phalaris plus double-cropping scenarios exceeded that for the equivalent annual pasture/crop scenarios and indicated scope for an alternative to annual pastures. However, much more research information on species physiology and agronomy, plus system management, is required before the feasibility of such an approach can be assessed.

\section{Water Use Efficiency}

The efficiency with which available water, from rainfall and irrigation, is used to grow pasture and crop DM, and with which DM is converted to animal production, are critical factors contributing to performance of dairy systems in northern Victoria. Many factors influence these relationships. Armstrong et al. (2000) observed a large range in WUE (reported as kilograms of milk solids per megaliter of total water) and in key productivity indicators among farms in a survey of 170 irrigated dairy businesses in northern Victoria and southern New South Wales. Farms in the top $10 \%$ of the survey population for WUE achieved $11.5 \mathrm{t}$ of pasture DM consumed per hectare, $1.0 \mathrm{t}$ of pasture DM consumed per megaliter of water (rainfall plus irrigation), and $1,076 \mathrm{~kg}$ of milk solids/ha with $0.87 \mathrm{t}$ of concentrate fed per cow, whereas the equivalent numbers for farms that achieved average WUE were 9.0, 0.8, 752, and 0.67. In the modeling analysis reported here, corresponding figures for the base farm were $12.6 \mathrm{t}$ of pasture DM consumed per hectare, $1.1 \mathrm{t}$ of pasture DM consumed per megaliter, and 1,715 kg of milk solids/ha. The high simulated milk solids production per hectare was due in part to higher levels of concentrate feeding $(1.87 \mathrm{t} / \mathrm{cow})$ compared with the farm survey information reported by Armstrong et al. (2000). The amounts of other imported feed used in the base simulation, plus other simulations conducted as part of this analysis, were also higher than those observed in the farm survey.
The predicted values of pasture consumed reported here, both per hectare and per megaliter of water, were similar to the top $10 \%$ values reported by Armstrong et al. (2000). However, the overall farm system WUE for all scenarios modeled here was higher than for farms surveyed by Armstrong et al. (2000): around 170 to $180 \mathrm{~kg}$ of milk solids/ML of total water compared with around $100 \mathrm{~kg}$ of milk solids/ML in the survey. Much of this difference could be due to higher stocking rates and imported feed use in the models. However, it also is likely that the models underestimate the amount of water required to grow crops and pastures in this environment, because they do not necessarily account for factors such as accelerated preferential water flow during the rewetting of soil after a dry summer (Bethune and Wang, 2004).

The estimated values for WUE of DM production for the different pastures and crops simulated by either DairyMod or APSIM were comparable with published data from field studies with the same species in northern Victoria and southern New South Wales (Table 5). The WUE of the simulated brassica crop was lower than that observed in the 2 published studies shown in Table 5. This could be because the APSIM simulation of brassica was actually for an oil seed canola crop, as APSIM does not presently include a submodel of forage brassica growth. The predicted WUE of irrigated annual ryegrass and maize was at the high end of the range of published values for these species, whereas the predicted WUE values for the 2 perennial pasture species aligned well with published information. It should be noted that the irrigation regimens and rainfall amounts in the field studies differed from those applied in the models; hence, direct relationships cannot be drawn between the simulated and observed data. Nonetheless, the comparisons presented in Table 5 support a reasonable level of confidence in the ability of the models to accurately represent the physiology underlying the pasture and crop yields that were used in the simulation of the different systems described here.

\section{Assumptions}

Many assumptions are necessary to carry out an analysis of the sort described here. The key assumptions to note include

a) Large shifts in water availability or price, or both, in the region are likely to drive more diversity in farming systems than is the case currently. The analysis described here was conducted on the assumption that a segment of the industry would continue to focus on forage-based production, 
Table 5. Comparison of water use efficiency (WUE; $\mathrm{kg}$ of DM/ha per millimeter of total water) of irrigated pastures and crops simulated using the DairyMod [Johnson et al., 2008; perennial ryegrass and Phalaris aquatica L. (Phalaris)] or Agricultural Production Systems Simulator (APSIM; Keating et al., 2003; annual ryegrass, maize, and brassica) models with published observed data

\begin{tabular}{|c|c|c|c|c|}
\hline Pasture/crop & Simulated WUE & \multicolumn{3}{|c|}{ Observed data } \\
\hline Perennial ryegrass & 14 & $\begin{array}{l}\text { Northern Vic } \\
\text { Northern Vic }\end{array}$ & $\begin{array}{l}10.5-13.3 \\
18-21\end{array}$ & $\begin{array}{l}\text { Lawson et al., } 2009 \\
\text { Mundy et al., } 2006\end{array}$ \\
\hline Phalaris & 19 & Northern Vic & $18-24$ & Mundy et al., 2006 \\
\hline Annual ryegrass (irrigated) & 31 & $\begin{array}{l}\text { Northern Vic } \\
\text { Northern Vic }\end{array}$ & $\begin{array}{l}11.9-15.1 \\
17-30\end{array}$ & $\begin{array}{l}\text { Lawson et al., } 2009 \\
\text { Stockdale, } 1986\end{array}$ \\
\hline Brassica & 23 & $\begin{array}{l}\text { Northern Vic } \\
\text { Camden NSW }\end{array}$ & $\begin{array}{l}31-46 \\
29\end{array}$ & $\begin{array}{l}\text { Hirth et al., } 2001 \\
\text { Garcia et al., } 2008\end{array}$ \\
\hline
\end{tabular}

${ }^{1}$ Vic $=$ Victoria $;$ NSW $=$ New South Wales.

emphasizing similar principles to the perennial ryegrass-based system (maximizing feed grown and used on the milking platform).

b) Excellent management of all farm operations was implicit in the simulations. Thus, the results do not take into account the effects of, for example, missed timing of sowing crop sequences in the double-crop rotation. The level of management skill required to operate the systems simulated here is probably greater than for the perennial ryegrass-based system and almost certainly greater risk is involved. These points must be borne in mind when considering the conclusions drawn from this analysis.

c) Where double cropping was included in the simulation forage plan, the proportion of farm area allocated to double cropping was constant at 0.3 of the irrigated land (except for the 115 cow scenarios with restricted water where the area of double crop was reduced to 0.22 of farm area because too much feed was produced for the number of cows from 0.3 of farm area). In practice, the amount of land under crop is flexible and should change between years, depending on factors such as water availability and total feed demand.

d) For the restricted irrigation scenarios, it was assumed that the same amount of water was available each year, whereas it may vary substantially between years (see allocations for 2006-2009 in Figure 1). Therefore, farmers may require more flexible water management policies to allow them to even out this variability (for example, through the ability to bank surplus water for use in years of low allocation). The production system itself will also need to incorporate the flexibility re- quired to deal with uneven water availability between years.

e) Similarly, the simulations described here used long-term mean seasonal pasture growth rates (from DairyMod, based on $47 \mathrm{yr}$ of climate data) whereas interannual variability in pasture supply is the norm in practice even when water is nonlimiting (Chapman et al., 2009). Interannual variability in conditions for plant growth will also apply to crops grown with limited, or zero, irrigation water, as is the case for several scenarios reported here. The outcomes of this variability could substantially alter the actual, and possibly also the relative, performance of the different farming systems that were modeled. This limitation of the modeling approach used here must also be considered when evaluating adaptation strategies for the region.

f) The WUE information from the pasture and crop models probably underestimates the total water required in reality, because inefficiencies in water use (for example higher bypass flow when refilling the soil profile during the first 1 to 2 irrigation events after a dry summer) are not accounted for.

g) Phalaris was used as the plant ideotype for the restricted water scenarios based on summerdormant perennial pasture species. When grown under rain-fed conditions in southern Australia, summer dormancy in Phalaris is released by the advent of late summer-autumn rain or cooler autumn temperatures, or both (Laude, 1953; McWilliam, 1968). It is not known whether the same environmental cues for release of dormancy in this species operate under irrigated conditions, or whether it is possible to switch on growth of 
this species with the high level of control exerted in the model. The ability to control dormancy quite precisely with irrigation is a key assumption in the perennial grass scenarios. Further research is required with Phalaris, or other plants with the desired trait, to determine whether or not the required level of control can be achieved in practice.

\section{CONCLUSIONS}

Based on the simulations conducted here, annual crops and pastures, or suitable summer-dormant perennial grass species, should be capable of supporting moderate levels of profitability if irrigation water allocations are restricted to 50 to $60 \%$ of historical levels. Under these circumstances, calving date, stocking rate, and supplementary feeding policies must change from the traditional approach so that homegrown forage is used efficiently. Even with these adaptations, the amount of homegrown feed consumed per hectare and per cow is likely to be well below levels considered necessary to sustain high profitability in pasture-based dairying. Farming systems adapted in the ways simulated here will be more complex to manage than traditional systems, and will almost certainly have higher exposure to business risk. Well-targeted research into the productivity and agronomy of crop and pasture species better suited to restricted water availability is clearly warranted to assist dairy producers to meet the challenge. This research must be conducted at the scale of the farm system, and should address how sufficient flexibility for dealing with year-to-year variability in irrigation water availability can be built into future farming systems.

\section{ACKNOWLEDGMENTS}

Funding support from the National Water Commission of Australia (Canberra, Australia) and the Victorian Water Trust (Melbourne, Australia) for this work is gratefully acknowledged.

\section{REFERENCES}

Armstrong, D. P., J. E. Knee, P. T. Doyle, K. E. Pritchard, and O. A. Gyles. 2000. Water-use efficiency on irrigated dairy farms in northern Victoria and southern New South Wales. Aust. J. Exp. Agric. 40:643-653.

Bethune, M., and Q. J. Wang. 2004. Simulating the water balance of border-check irrigated pasture on a cracking soil. Aust. J. Exp. Agric. 44:163-171.

Chapman, D. F., B. R. Cullen, I. R. Johnson, and D. Beca. 2009. Interannual variation in pasture growth rate in Australian and New Zealand dairy regions and its consequences for system management. Anim. Prod. Sci. 49:1071-1079.
Chapman, D. F., S. N. Kenny, D. Beca, and I. R. Johnson. 2008. Pasture and forage crop options for non-irrigated dairy farms in southern Australia. 1. Physical production and economic performance. Agric. Syst. 97:108-125.

Chiew, F. H. S., J. Vaze, N. R. Viney, P. W. Jordan, J.-M. Perraud, L. Zhang, J. Teng, W. J. Young, J. Penaarancibia, R. A. Morden, A. Freebairn, J. Austin, P. I. Hill, C. R. Wiesenfeld, and R. Murphy. 2008. Rainfall-runoff modeling across the Murray-Darling Basin. A report to the Australian Government from the Commonwealth Scientific and Industrial Research Organisation (CSIRO) MurrayDarling Basin Sustainable Yields Project. CSIRO, Canberra, Australia.

CSIRO and BOM (Commonwealth Scientific and Industrial Research Organisation and Bureau of Meteorology). 2007. Climate change in Australia. Technical report 2007. K. B. Pearce, P. N. Holper, M. Hopkins, W. J. Bouma, P. H. Whetton, K. J. Hensessy, and S. B. Power, ed. CSIRO Marine and Atmospheric Research, Aspendale, Victoria, Australia. Accessed Sep. 4, 2011. http://www. climatechangeinaustralia.gov.au.

Edraki, M., E. Humphreys, and N. O'Connell. 2003. Soil water dynamics and components of water balance for irrigated lucerne in southern NSW. Commonwealth Scientific and Industrial Research Organisation (CSIRO) Land and Water, Griffith, NSW, Australia.

Farré, I., M. J. Robertson, G. H. Walton, and S. Asseng. 2001. Simulating response of canola to sowing date in Western Australia. In Proc. 10th Australian Agronomy Conference, Hobart, Tasmania, Australia. http://www.agronomy.org.au.

Garcia, S. C., W. J. Fulkerson, and S. U. Brookes. 2008. Dry matter production, nutritive value and efficiency of nutrient utilization of a complementary forage rotation compared to a grass pasture system. Grass Forage Sci. 63:284-300.

Godbold, N. 1989. Victoria Cream of the Country. A History of Victorian Dairying. Dairy Industry Association of Victoria, Melbourne, Victoria, Australia.

Greenwood, K. L., G. N. Mundy, and K. B. Kelly. 2008. On-farm measurement of the water use and productivity of maize. Aust. J. Exp. Agric. 48:274-284.

Hirth, J. R., P. J. Haines, A. M. Ridley, and K. F. Wilson. 2001. Lucerne in crop rotations on the Riverine Plains 2. Biomass and grain yields, water use efficiency, soil nitrogen, and profitability. Aust. J. Agric. Res. 52:279-293.

Johnson, I. R., D. F. Chapman, V. O. Snow, R. J. Eckard, A. J. Parsons, M. G. Lambert, and B. R. Cullen. 2008. DairyMod and EcoMod: Biophysical pasture-simulation models for Australia and New Zealand. Aust. J. Exp. Agric. 48:621-631.

Jones, R., and P. Durack. 2005. Estimating the Impacts of Climate Change on Victoria's Runoff using a Hydrological Sensitivity Model. Commonwealth Scientific and Industrial Research Organisation (CSIRO) Atmospheric Research, Melbourne, Victoria, Australia.

Jones, R., P. Whetton, K. Walsh, and C. Page. 2001. Future Impact of Climate Variability, Climate Change and Land Use on Water Resources in the Murray-Darling Basin. Overview and Draft Program of Research. Commonwealth Scientific and Industrial Research Organisation (CSIRO), Canberra, Australia.

Keating, B. A., P. S. Carberry, G. L. Hammer, M. E. Probert, M. J. Robertson, D. Holzworth, N. I. Huth, J. N. G. Hargreaves, H. Meinke, Z. Hochman, G. McLean, K. Verburg, V. Snow, J. P. Dimes, M. Silburn, E. Wang, S. Brown, K. L. Bristow, S. Asseng, S. Chapman, R. L. McCown, D. M. Freebairn, and C. J. Smith. 2003. An overview of APSIM, a model designed for farming systems simulation. Eur. J. Agron. 18:267-288.

Larcombe, M. T. 1989. The effects of manipulating reproduction on the productivity and profitability of dairy herds which graze pasture. PhD Thesis. Faculty of Veterinary Science, University of Melbourne, Victoria, Australia.

Laude, H. M. 1953. The nature of summer dormancy in perennial grasses. Bot. Gaz. 114:284-292

Lawson, A. R., K. L. Greenwood, and K. B. Kelly. 2009. Irrigation water productivity of winter-growing annuals is higher than perennial forages in northern Victoria. Crop Pasture Sci. 60:407-419. 
Martin, P., D. Riley, M. Lubulwa, P. Knopke, and T. Gleeson. 2000. Australian Dairy Industry 2000, A Report of the Australian Dairy Industry Survey. Australian Bureau of Agricultural and Resource Economics (ABARE) Research Report 2000.10, Canberra, ACT, Australia.

McWilliam, J. R. 1968. The nature of the perennial response in Mediterranean grasses 2. Senescence, summer dormancy and survival in Phalaris. Aust. J. Agric. Res. 19:397-409.

Mickan, F. J., M. D. Martin, and J. W. Piltz. 2003. Silage storage. Pages 1-36 in Top Fodder: Successful Silage. A. G. Kaiser, J. W. Piltz, J. M. Burns, and N. W. Griffiths, ed. Dairy Research and Development Corporation and NSW Agriculture. Southbank, Victoria, Australia.

Mundy, G. N. 1999. A review of nitrogen research with irrigated pastures in northern Victoria. Department of Natural Resources and Environment. Victoria, Australia. Accessed Jan. 9, 2012. http:// www.nitrogen.unimelb.edu.au/Irrigreview.htm.

Mundy, G. N., K. Greenwood, K. Kelly, S. M. Austin, and K. E. Dellow. 2006. Improved soil and irrigation management for forage production 3. Plant-soil-water relationships. Aust. J. Exp. Agric. 46:327-335.

Neal, J. S., W. J. Fulkerson, R. Lawrie, and I. M. Barchia. 2009. Difference in yield and persistence among perennial forages used by the dairy industry under optimum and deficit irrigation. Crop Pasture Sci. 60:1071-1087.

Nie, Z. N., D. F. Chapman, J. Tharmaraj, and R. Clements. 2004. Effects of pasture species mixture, management, and environment on the productivity and persistence of dairy pastures in south-west Victoria. 2. Plant population density and persistence. Aust. J. Agric. Res. 55:637-643.

Norton, M. R., F. Lelievre, S. Fukai, and F. Volaire. 2008. Measurement of summer dormancy in temperate perennial pasture grasses. Aust. J. Agric. Res. 59:498-509.
Oram, R. N., and R. A. Culvenor. 1994. Phalaris improvement in Australia. N. Z. J. Agric. Res. 37:329-339.

Robertson, M. J., J. F. Holland, J. A. Kirkegaard, and C. J. Smith. 1999. Simulating growth and development of canola in Australia. In Proc. 10th International Rapeseed Congress. CD-Rom Proc. The Regional Institute, Gosford, NSW, Australia.

Sinclair, T. R., and R. C. Muchow. 1995. Effect of nitrogen supply on maize yield: I. Modeling physiological responses. Agron. J. 87:632-641.

Stockdale, C. R. 1986. Factors affecting the productivity of irrigated annual pastures. 1. Time of first irrigation in late summer-early autumn. Aust. J. Exp. Agric. 26:297-304.

Stockdale, C. R. 2010. Wastage of conserved fodder when feeding livestock. Anim. Prod. Sci. 50:400-404.

Thomas, H. 1991. Accumulation and consumption of solutes in swards of Lolium perenne during drought and after rewatering. New Phytol. 118:35-48.

Volaire, F., H. Thomas, N. Bretagne, E. Bourgeois, M.-F. Gautier, and F. Lelièvre. 1998a. Survival and recovery of perennial forage grasses under prolonged Mediterranean drought. II. Water status, solute accumulation, abscisic acid concentration and accumulation of dehydrin transcripts in bases of immature leaves. New Phytol. 140:451-460.

Volaire, F., H. Thomas, and F. Lelievre. 1998b. Survival and recovery of perennial forage grasses under prolonged Mediterranean drought. I. Growth, death, water relations and solute content in herbage and stubble. New Phytol. 140:439-449.

Waller, R. A., and P. W. G. Sale. 2001. Persistence and productivity of perennial ryegrass in sheep pasture in south-western Victoria: A review. Aust. J. Exp. Agric. 41:117-144.

Wilson, D. R., R. C. Muchow, and C. J. Murgatroyd. 1995. Model analysis of temperature and solar radiation limitations to maize potential productivity in a cool climate. Field Crops Res. 43:1-18.

\section{APPENDIX}

Table A1. Key variables and associated parameter values used in the DairyMod (Johnson et al., 2008) model to simulate growth of perennial ryegrass, annual ryegrass, and Phalaris aquatica L. (Phalaris) pastures receiving irrigation on a texture contrast soil

\begin{tabular}{|c|c|c|c|}
\hline Variable & $\begin{array}{c}\text { Perennial } \\
\text { ryegrass }\end{array}$ & $\begin{array}{c}\text { Annual } \\
\text { ryegrass }\end{array}$ & Phalaris \\
\hline \multicolumn{4}{|l|}{ Plant variable } \\
\hline Maximum photosynthetic rate at reference temperature ( $\mathrm{mg}$ of $\mathrm{CO}_{2} / \mathrm{m}^{2}$ per second) & 1 & 1 & 1 \\
\hline $\mathrm{C}$ partitioned to total shoot ( $\%$ of total net $\mathrm{C}$ assimilated) & 80 & 80 & 80 \\
\hline $\mathrm{C}$ partitioned to root (\% of total net $\mathrm{C}$ assimilated) & 20 & 20 & 20 \\
\hline $\mathrm{C}$ partitioned to leaf ( $\%$ of $\mathrm{C}$ partitioned to total shoot) & 70 & 70 & 60 \\
\hline Transfer of dead material to litter at reference temperature $(\% / d)$ & 10 & 12.5 & 10 \\
\hline Maximum root depth $(\mathrm{cm})$ & 40 & 40 & 150 \\
\hline Depth to $50 \%$ of root mass $(\mathrm{cm})$ & 15 & 15 & 30 \\
\hline Root senescence rate at reference temperature ( $\%$ total live weight/d) & 2 & 2 & 2 \\
\hline Initial shoot dry weight ( $\mathrm{t}$ of $\mathrm{DM} / \mathrm{ha})$ & 2.5 & 1 & 1 \\
\hline Fraction of green material in initial shoot weight $(\%)$ & 80 & 75 & 50 \\
\hline Initial root dry weight (t of DM/ha) & 1 & 1 & 1 \\
\hline Trigger for start of watering ( $\%$ field capacity) & 65 & - & 75 \\
\hline Upper limit for cessation of watering (\% field capacity) & 100 & - & 100 \\
\hline
\end{tabular}

${ }^{1}$ The reference temperature for plant variables was $20^{\circ} \mathrm{C}$. 
Table A2. Key variables and associated parameter values used in the Agricultural Production Systems Simulator (APSIM; Keating et al., 2003) model to simulate growth of maize, brassica, and annual ryegrass crops

\begin{tabular}{|c|c|c|c|}
\hline Variable & Maize & Brassica & Annual ryegrass \\
\hline \multicolumn{4}{|l|}{ Plant variable } \\
\hline Cultivar & NSCM_41 & Mid & Late \\
\hline Maturity & Early & Mid & Late \\
\hline Harvest rules & At maturity or Mar 15 & $\begin{array}{l}\text { Cut to } 50 \mathrm{~mm} \text { and remove } \\
90 \% \text { of above-ground biomass } \\
\text { on Jun } 30 \text { and Oct } 10\end{array}$ & $\begin{array}{l}\text { Cut to } 50 \mathrm{~mm} \text { and remove } 90 \% \\
\text { of above ground biomass when } \\
\text { DM exceeds } 3,000 \mathrm{~kg} / \mathrm{ha} \text { until } \\
\text { mid Aug, and on Oct } 10\end{array}$ \\
\hline Planting density (plants $/ \mathrm{m}^{2}$ ) & 8 & 80 & 500 \\
\hline Fertilizer & Nonlimiting nutrients & Nonlimiting nutrients & Nonlimiting nutrients \\
\hline Irrigation variable & $\begin{array}{l}\text { Deficit irrigation } \\
\text { Oct } 15 \text { to maturity } \\
\text { or Mar } 15\end{array}$ & $\begin{array}{l}\text { Deficit irrigation } \\
\text { From sowing to Apr } \\
\text { 30; Sep 1-Oct } 10\end{array}$ & $\begin{array}{l}\text { Deficit irrigation } \\
\text { From sowing to Apr } \\
\text { 30; Sep 1-Oct } 10\end{array}$ \\
\hline
\end{tabular}

Table A3. Parameter values used in the DairyMod (Johnson et al., 2008) and Agricultural Production Systems Simulator (APSIM; Keating et al., 2003) models to describe the soil at Dookie, northern Victoria, Australia, for the purposes of simulating pasture growth rates

\begin{tabular}{|c|c|c|c|c|}
\hline \multirow[b]{2}{*}{ Item } & \multicolumn{4}{|c|}{ Soil profile layer } \\
\hline & Surface & $\mathrm{A}$ & B1 & $\mathrm{B} 2$ \\
\hline \multicolumn{5}{|l|}{ Soil profile description } \\
\hline Depth to bottom of horizon $(\mathrm{cm})$ & 2 & 15 & 60 & 150 \\
\hline Texture & $\mathrm{Sa}-\mathrm{Cly}-\mathrm{L}^{1}$ & Sa-Cly-L & $\mathrm{Cly}^{2}$ & Cly \\
\hline Saturated water content ( $\%$ volume $)$ & 48 & 44 & 44 & 46 \\
\hline Saturated hydraulic conductivity $(\mathrm{cm} / \mathrm{d})$ & 114 & 108 & 14 & 0.03 \\
\hline Field capacity (\% volume) & 36 & 37 & 38 & 39 \\
\hline Wilting point (\% volume) & 18 & 25 & 27 & 29 \\
\hline Air dry water content ( $\%$ volume $)$ & 11 & 22 & 24 & 27 \\
\hline \multicolumn{5}{|l|}{ Soil variable } \\
\hline Initial water content to wilting point $(\mathrm{mm})$ & \multicolumn{4}{|c|}{274} \\
\hline Organic $\mathrm{C}$ content of the surface soil ( $\%$ mass) & \multicolumn{4}{|c|}{5.0} \\
\hline Organic $\mathrm{C}$ content to $10-\mathrm{cm}$ depth (\% mass) & \multicolumn{4}{|c|}{4.7} \\
\hline $\mathrm{C}: \mathrm{N}$ ratio of $\mathrm{OM}$ & \multicolumn{4}{|c|}{8.0} \\
\hline Rate of decay of fast turnover pool of OM (\%/d) & \multicolumn{4}{|c|}{1.5} \\
\hline Rate of decay of slow turnover pool of OM $(\% / d)$ & \multicolumn{4}{|c|}{0.012} \\
\hline Half life of fast turnover pool of OM (d) & \multicolumn{4}{|c|}{46} \\
\hline Half life of slow turnover pool of $\mathrm{OM}(\mathrm{yr})$ & \multicolumn{4}{|c|}{15.8} \\
\hline
\end{tabular}

${ }^{1}$ Sandy clay loam.

${ }^{2}$ Clay. 
Table A4. Parameter values used in the UDDER (Larcombe, 1989) model to describe the dairy herds and feeds used in simulations and calculate milk income, production costs, and operating surplus

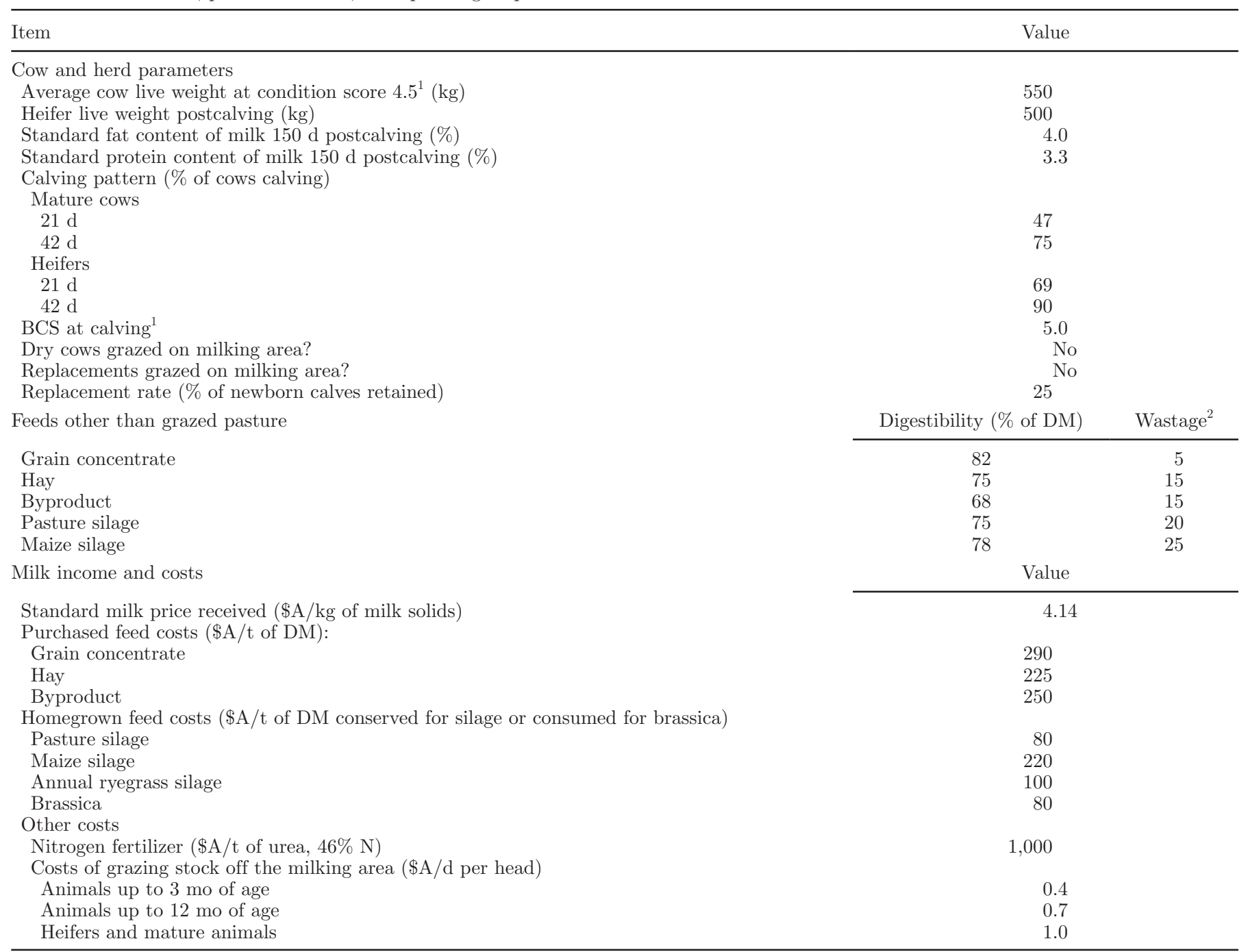

${ }^{1}$ Body condition score is on a scale of 1 to $8(1=$ thin and $8=$ fat $)$.

${ }^{2}$ For grain, hay, and byproduct, wastage was assumed to apply only during feeding and is expressed as percentage of total DM offered; for pasture silage, maize silage, and annual ryegrass silage, wastage includes losses during conservation and feeding and is expressed as percentage of total DM of the standing crop. 
Table A5. Simulated physical and financial performance of a 45-ha irrigated dairy farm in northern Victoria, Australia with $100 \%$ irrigation water allocation and based on either fully irrigated perennial pasture (base simulation) or perennial pasture plus double cropping with maize in summer, followed by either brassica or annual ryegrass in winter ( 0.7 and 0.3 of effective farm area in pasture and crop, respectively) at a range of stocking rates

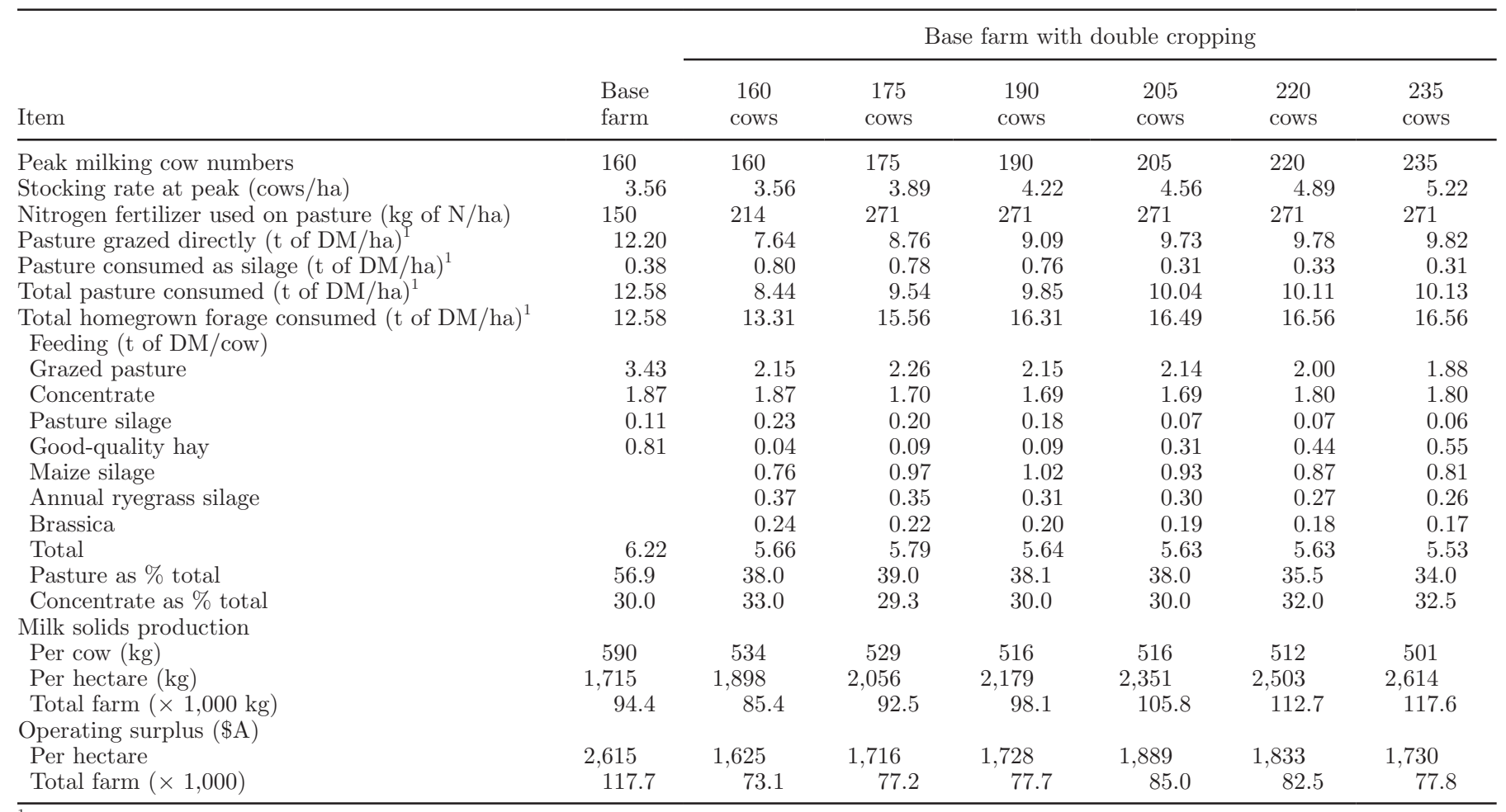

${ }^{1}$ Values are for total farm effective area (45 ha). To convert pasture consumption rates to area of pasture only ( $70 \%$ of total), divide by 0.7 . 
Table A6. Simulated physical and financial performance of a 45-ha irrigated dairy farm in northern Victoria, Australia with zero irrigation water allocation with calving starting in different months ${ }^{1}$

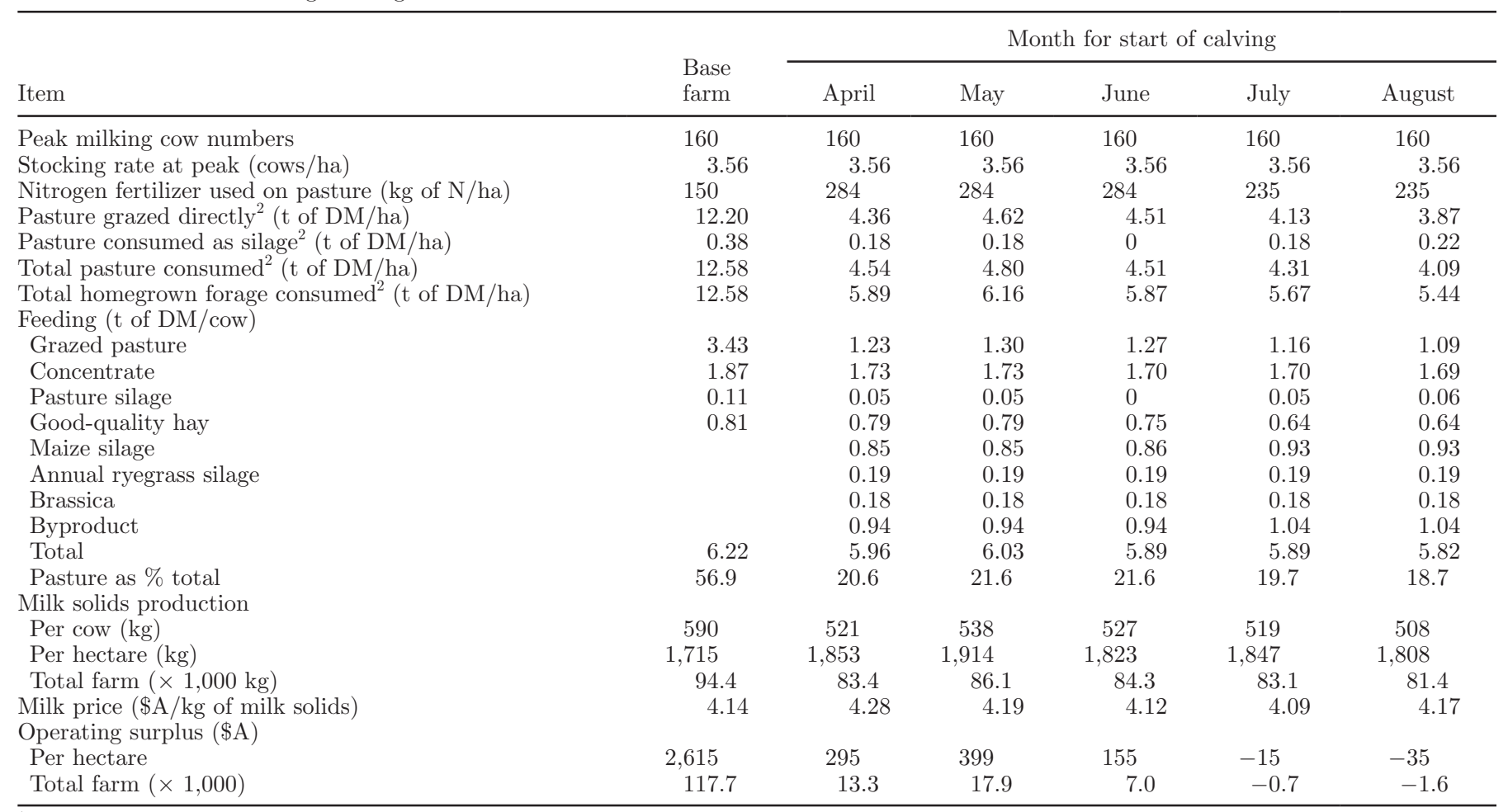

${ }^{1}$ In all cases, the forage base is nonirrigated annual pasture ( 0.7 of effective farm area) and nonirrigated annual crops (brassica for grazing, 0.15 of farm area; annual ryegrass for silage, 0.15 of farm area). The base farm simulation ( $100 \%$ water allocation, 1.0 of farm area in perennial pasture, calving starting in August) is included for comparison.

${ }^{2}$ Values are for total farm effective area (45 ha). To convert pasture consumption rates to area of pasture only ( $70 \%$ of total), divide by 0.7 . 
Table A7. Simulated physical and financial performance of a 45-ha irrigated dairy farm in northern Victoria, Australia with restricted irrigation water allocation and based on annual pasture plus double cropping with maize in summer, followed by either brassica or annual ryegrass in winter ( 0.7 and 0.3 of effective farm area in pasture and crop, respectively), with calving starting in May or August, at a range of stocking rates ${ }^{1}$

\begin{tabular}{|c|c|c|c|c|c|c|c|}
\hline Item & $\begin{array}{l}\text { Base } \\
\text { farm }\end{array}$ & \multicolumn{3}{|c|}{ May calving } & \multicolumn{3}{|c|}{ August calving } \\
\hline Stocking rate at peak (cows/ha) & 3.56 & 2.56 & 3.56 & 4.56 & 2.56 & 3.56 & 4.56 \\
\hline Nitrogen fertilizer used on pasture (kg of N/ha) & 150 & 75 & 75 & 75 & 135 & 270 & 270 \\
\hline Pasture grazed directly ${ }^{3}(\mathrm{t}$ of $\mathrm{DM} / \mathrm{ha})$ & 12.20 & 5.11 & 5.47 & 6.29 & 4.58 & 4.42 & 4.93 \\
\hline \multicolumn{8}{|l|}{ Feeding ( $\mathrm{t}$ of $\mathrm{DM} / \mathrm{cow})$} \\
\hline Grazed pasture & 3.43 & 2.00 & 1.54 & 1.38 & 1.79 & 1.28 & 1.08 \\
\hline Concentrate & 1.87 & 1.91 & 2.10 & 2.10 & 1.89 & 2.08 & 2.08 \\
\hline Pasture silage & 0.11 & 0.50 & 0.27 & 0.21 & 0.55 & 0.61 & 0.48 \\
\hline Good-quality hay & 0.81 & 0 & 0.19 & 0.70 & 0.05 & 0.19 & 0.69 \\
\hline Maize silage & & 1.18 & 1.19 & 0.93 & 1.16 & 1.20 & 0.93 \\
\hline \multicolumn{8}{|l|}{ Milk solids production } \\
\hline Per cow (kg) & 590 & 582 & 574 & 549 & 571 & 560 & 530 \\
\hline Per hectare (kg) & 1,715 & 1,488 & 2,041 & 2,502 & 1,459 & 1,990 & 2,415 \\
\hline Total farm $(\times 1,000 \mathrm{~kg})$ & 94.4 & 70.0 & 91.8 & 112.6 & 65.6 & 89.6 & 108.7 \\
\hline \multicolumn{8}{|l|}{ Operating surplus $(\$ A)$} \\
\hline Per hectare & 2,615 & 1,207 & 1,684 & 1,746 & 949 & 1,055 & 1,001 \\
\hline Total farm $(\times 1,000)$ & 117.7 & 54.3 & 75.8 & 78.6 & 42.7 & 47.5 & 45.0 \\
\hline
\end{tabular}

${ }^{1}$ The base farm simulation (100\% water allocation, 1.0 of farm area in perennial ryegrass pasture, calving starting in August) is included for comparison.

${ }^{2}$ The forage plan for 115-cow simulations was amended to 0.78:0.22 ratio of annual pasture to double crop, expressed as proportion of total effective farm area.

${ }^{3}$ Values are for total farm effective area (45 ha). To convert pasture consumption rates to area of pasture only, divide by 0.70 for 160 - and 205 cow simulations, and 0.78 for 115 -cow simulations. 
Table A8. Simulated physical and financial performance of a 45-ha irrigated dairy farm in northern Victoria, Australia with restricted irrigation water allocation and based on partially irrigated Phalaris aquatica L. (Phalaris) pasture plus double cropping with maize in summer, followed by either brassica or annual ryegrass in winter ( 0.7 and 0.3 of effective farm area in pasture and crop, respectively) at a range of stocking rates, with calving starting in May ${ }^{1}$

\begin{tabular}{|c|c|c|c|c|}
\hline Item & Base farm & 115 cows $^{2}$ & 160 cows & 205 cows \\
\hline Stocking rate at peak (cows/ha) & 3.56 & 2.56 & 3.56 & 4.56 \\
\hline Nitrogen fertilizer used on pasture ( $\mathrm{kg}$ of $\mathrm{N} / \mathrm{ha}$ ) & 150 & 115 & 156 & 156 \\
\hline Pasture consumed as silage $^{3}$ (t of DM/ha) & 0.38 & 1.31 & 0.62 & 0 \\
\hline Total pasture consumed ${ }^{3}(\mathrm{t}$ of $\mathrm{DM} / \mathrm{ha})$ & 12.58 & 8.00 & 7.86 & 8.29 \\
\hline Total homegrown forage consumed ${ }^{3}(\mathrm{t}$ of $\mathrm{DM} / \mathrm{ha}$ ) & 12.58 & 10.64 & 12.40 & 15.71 \\
\hline Concentrate & 1.87 & 1.42 & 1.96 & 1.96 \\
\hline Pasture silage & 0.11 & 0.51 & 0.17 & 0 \\
\hline Good-quality hay & 0.81 & 0 & 0.49 & 0.50 \\
\hline Maize silage & & 0.64 & 0.58 & 1.00 \\
\hline Annual ryegrass silage & & 0.30 & 0.31 & 0.31 \\
\hline Brassica & & 0.26 & 0.26 & 0.20 \\
\hline Total & 6.22 & 5.75 & 5.80 & 5.79 \\
\hline Total farm $(\times 1,000 \mathrm{~kg})$ & 94.4 & 61.2 & 84.4 & 107.8 \\
\hline \multicolumn{5}{|l|}{ Operating surplus $(\$ \mathrm{~A})$} \\
\hline Per hectare & 2,615 & 1,517 & 1,734 & 1,852 \\
\hline Total farm $(\times 1,000)$ & 117.7 & 68.3 & 78.0 & 83.4 \\
\hline
\end{tabular}

${ }^{1}$ The base farm simulation (100\% water allocation, 1.0 of farm area in perennial ryegrass pasture, calving starting in August) is included for comparison.

${ }^{2}$ The forage plan for 115-cow simulations was amended to a 0.78:0.22 ratio of annual pasture to double crop, expressed as proportion of total effective farm area.

${ }^{3}$ Values are for total farm effective area (45 ha). To convert pasture consumption rates to area of pasture only, divide by 0.70 for $160-$ and 205 cow simulations, and 0.78 for 115 -cow simulations. 